VOX PATRUM 25 (2005) t. 48

Mieczysław C. PACZKOWSKI OFM

(Wrocław - Toruń, UMK)

\title{
CHRYSTOLOGIA HIERONIMA NA TLE TEOLOGII PALESTYŃSKIEJ PRZEIOMU IV I V WIEKU
}

Hieronim ze Strydonu znany jest przede wszystkim jako egzegeta i tłumacz, lecz nie sposób pominąć jego roli w rozwoju teologii. Można go uważać za jednego $\mathrm{z}$ czołowych przedstawicieli chrystologii przedchalcedońskiej rozwijającej się w kręgach palestyńskich. Postać autora Wulgaty łączy się z dyskusjami teologicznymi podejmowanymi na Bliskim Wschodzie, w których brali aktywny udział przybysze $\mathrm{z}$ całego ówczesnego chrześcijańskiego świata. Hieronim nie był pierwszym $z$ tych, którzy znaleźli w Palestynie nową ojczyznę. $\mathrm{Na}$ przełomie IV i V wieku podobne epizody w biografiach wielu osób były niemal na porządku dziennym.

Pobyt Hieronima na Wschodzie miał również inny aspekt: podobnie, jak w przypadku Hilarego z Poitiers, doszło do bezpośredniego kontaktu autora łacińskiego $\mathrm{z}$ teologicznym dziedzictwem Wschodu. Strydończyk zetknął się z dwoma teologami, którzy reprezentowali dwie odrębne pozycje w refleksji nad dogmatem chrystologicznym: byli to Apolinary ${ }^{1}$ i Dydym Ślepy ${ }^{2}$.

W 385 r. Hieronim opuszcza ostatecznie Rzym - Babilonię i udaje się na Wschód. Ma to miejsce po śmierci papieża Damazego. Swój krok Hieronim

${ }^{1}$ Apolinary z Laodycei znalazl się w sytuacji otwartego konfliktu doktrynalnego w Kościele, który stawiał wyzwania natury apologetycznej. Biskup Laodycei reprezentuje tradycję teologiczną o wyraźnych rysach maloazjatyckich. $Z$ drugiej strony ma się do czynienia $z$ mistrzem egzegezy, chociaż trudno o niej coś bliższego powiedzieć ze względu na fragmentaryczność zachowanych dziel tego autora, por. listę fragmentów dzieł egzegetycznych Apolinarego w: M. Geerard, Clavis Patrum Graecorum (= CPG), II, Turnhout 1974, 3680-3695.

${ }^{2}$ Dydym Slepy kierował w IV wieku szkołą teologiczną w Aleksandrii. Co prawda nie był on myślicielem całkowicie oryginalnym, lecz jedną z największych jego zasług była wiernośc zasadom egzegezy aleksandryjskiej. Fakt ten nie podlega dyskusji, gdyż w zachowanych pismach Dydym sprawia wrażenie przekonanego alegorysty, który (jak zresztą każdy dobry egzegeta aleksandryjski) uważa, że dosłowny tekst biblijny stanowi pożywkę wylącznie dla masy prostych wiernych: kto pragnie wznieś́ się ponad ten poziom ,,prostaczków”, winien zbliżyć się do interpretacji duchowej. Rufin niezbyt docenia pobyt w kręgu uczniów Dydyma, por. Apologia contra Hieronymum II 15, CCL 20, 94-95. Hieronim zestawia opinie obu teologów i stwierdza: „Jest rzeczą pewną, że jeśli porówna się nauczanie Apolinarego i Dydyma, to jest ono różne" (Epistula 84, 3, CSEL 55, 123). 
wyjaśnia w liście do Aselli ${ }^{3}$. Chodzi o jego powtórną podróż do tego zakątka świata po doświadczeniach surowego życia ascetycznego na pustyni Kalcis w latach 376-3794. Wielki egzegeta łaciński osiada w Betlejem i przebywa tam aż do końca życia. Wybiera Palestynę jako swoją "drugą ojczyznę" z powodów duchowych i erudycyjnych: celem Hieronima było zgłębianie Słowa Bożego przez kontakt ze środowiskiem, gdzie Ono przyoblekło się w człowieczeństwo ${ }^{5}$. Betlejem stało się dla niego „miejscem pobytu”, ponieważ była to „ojczyzna (patria) Pana [...]. Pozostałem tam, ponieważ wybrał je Zbawiciel"6. Strydończyk potwierdzał niejednokrotnie ten ciepły stosunek do miasta Narodzenia Pańskiego ${ }^{7}$. W miejscu Narodzenia Chrystusa poświęca się on działalności pisarskiej, polemicznej i egzegetycznej. Jest to jeden $z$ najowocniejszych okresów nie tylko w życiu Hieronima, ogarniętego niezwykłą „pasją naukową", ale i w całej historii literatury chrześcijańskiej.

Rozpoczynając życie mnicha w Betlejem, Strydończyk stał się jednym z przedstawicieli międzynarodowej wspólnoty, która odcisnęła swoje piętno na obliczu Kościoła bliskowschodniego. Począwszy od IV wieku historia odnotowała szereg imion osób odwiedzających Jerozolimę, a niektórzy pątnicy zostawili opis swojej pielgrzymki ${ }^{8}$. Do grona znamienitszych pielgrzymów należał również Rufin z Akwilei, który wspólnie z Hieronimem w Palestynie podjął trud tłumaczenia dzieł Orygenesa.

Postać Hieronima wskazuje na niezwykle ważną charakterystykę panoramy religijnej Palestyny chrześcijańskiej w okresie późnego antyku, która staje się nie tylko celem pielgrzymek, ale również jednym z głównych ośrodków monastycyzmu wschodniego. Nie sposób pozostawić na uboczu tego nowego elementu życia eklezjalnego, chcąc przyjrzeć się $z$ właściwej perspektywy dyskusjom chrystologicznym. Życie monastyczne w Palestynie, rozwijające się zarówno dzięki miejscowym powołaniom, jak i przybyszom, z czasem stało się decydującym czynnikiem $w$ dalszym rozwoju teologii. Strydończyk jest zaledwie jednym $z$ ogniw długiego łańcucha przedstawicieli nurtu monastycznego w refleksjach teologicznych ${ }^{9}$. W następnych dziesięcioleciach nie zabrak-

${ }^{3}$ Jest to Epistula 45 (CSEL 54, 323-328, thum. J. Czuj: Sw. Hieronim, Listy, I, Warszawa 1952, 251-255) o charakterze pożegnalnym. W liście tym Hieronim wylewa calą swą gorycz z powodu stylu życia tzw. „dobrych chrześcijan” w Rzymie.

"Odnośnie tej podróży, por. I. Grego, Girolamo nella sua „povera piccola Betlemme”. Il XVI centenario della venuta di san Girolamo a Betlemme, ,Studia Orientalia Christiana. Collectanea” 19 (1986) 246-248.

5 Por. A. Penna, Principi e carattere dell'esegesi di S. Girolamo, Roma 1950, 205-206.

${ }^{6}$ Epistula 108, 10, CSEL 55, 318. Hieronim nazywa Betlejem „naszym”, por. Epistula 58, 3.

7 Por. Epistula 58, 3, CSEL 54, 532: „Betlejem to najszlachetniejsze miejsce na świecie”.

${ }^{8}$ Najbardziej reprezentatywne to Itinerarium Burdigalense (CCL 175, 1-26) i Peregrinatio Egeriae (CCL 175, 37-90).

9 Por. L. Perrone, "Four Gospels, Four Councils" - One Lord Jesus Christ. The Patristic Developments of Christology within the Church of Palestine, „Liber Annuus” 49 (1999) 377-378. 
nie analogii, przede wszystkim w przypadku mnichów z Pustyni Judzkiej, jak Eutymiusz, Saba i Teodozjusz, którzy byli przybyszami spoza granic Palestyny. $\mathrm{W}$ epoce Hieronima $\mathrm{z}$ pewnością wiele innych czynników oprócz emigracji złożyło się na umocnienie się monastycyzmu, który przecież odcisnął swoje piętno na rozwoju myśli teologicznej i był decydującym czynnikiem w sporach doktrynalnych.

\section{KONTEKSTUALIZACJA CHRYSTOLOGII}

Rozważania Hieronima mogą być doskonale połączone $\mathrm{z}$ niespokojną atmosferą konfliktów dotyczących doktryny o Chrystusie, Bogu - człowieku. Nie chodzi tu jednak o refleksję teologa czystej wody. Zainteresowania biblijne Strydończyka ${ }^{10}$ stawiają go $\mathrm{w}$ szeregu autorów korzystających ze spuścizny Orygenesa, najważniejszego poprzednika egzegetów złotego okresu literatury patrystycznej i stawianego często jako wzór dla nich. Chrystologia Hieronima jawi się na tle wielkiej tradycji studiów nad Biblią. Mimo ataków na Rufina, Jana Jerozolimskiego i ugrupowanie orygenistów, wpływy Orygenesa są niewątpliwe. Autor Wulgaty być może uległby im w mniejszym stopniu, gdyby nie jego specyficzna formacja literacka i intelektualna. Do propagowania myśli wielkiego Aleksandryjczyka przyczyniły się dzieła jego zwolenników i osobiste kontakty pomiędzy tymi autorami, którzy pozostawali pod jego przemożnym wpływem. Palestyna była terenem, gdzie przyjacielska wymiana poglądów i manuskryptów zawierających dzieła Orygenesa była dosyć znacząca. Nad wpływami aleksandryjskimi czasami przeważa nastawienie pastoralne, jak to ukazują katechezy Cyryla i Jana z Jerozolimy.

1. Teologia palestyńska wobec tajemnicy Chrystusa. Hieronim zwrócił uwagę na zdobycze szkoły egzegetyczno-teologicznej z Cezarei Nadmorskiej, gdzie alegoryzm aleksandryjski zostaje uzupełniony przez lekturę historycznotypologiczną rodem z Antiochii. Ten ślad pozostawia jednak pewien niedosyt, bowiem sylwetkę Hieronima - teologa kształtowali również wcześniejsi autorzy związani z Palestyną. $\mathrm{Z}$ tych względów warto przyjrzeć się trzem z nich: Orygenesowi, Euzebiuszowi z Cezarei i Cyrylowi Jerozolimskiemu.

Przed Orygenesem, oprócz śladów pozostawionych przez teologów judeochrześcijańskich, nie ma wyraźnych oznak szczególnego ożywienia w dziedzinie teologicznej Palestyny. Było tak mimo wysiłków podjętych przez Egezypa, a następnie Euzebiusza z Cezarei, bowiem było wiele powodów, dla których

${ }^{10}$ Hieronim preferowal egzegezę starotestamentalną (Psalterz i opus prophetale) i tylko wyjątkowo zajmował się Nowym Testamentem, jak czwartą Ewangelią, por. A. Penna, Conferenze bibliche di S. Girolamo, „Rivista Biblica Italiana” 1 (1949) 153. 
w historii teologii Palestyna jawiła się jako terra incognita. Wiadomo jednak, że Kościół judeochrześcijański nie był jednolity, a wśród jego wyznawców palestyńskich wyróżniano ebionitów i nazarejczyków. Przedstawiciele pierwszej grupy uważali się za duchowych spadkobierców Jakuba Starszego, chociaż $\mathrm{z}$ czasem ich doktryna przyjęła heterodoksyjny charakter. Ebionici ${ }^{11}$ pochodzili ze starych kręgów hebrajskich, stąd też ściśle przestrzegali prawa Mojżeszowego. Chrystus był dla nich jedynie człowiekiem wyróżniającym się szczególną mocą ${ }^{12}$. U ebionitów widać przedłużenie mesjanizmu judaistycznego o charakterze materialnym, uzależnionym od dosłownej interpretacji proroctw ${ }^{13}$. Nazarejczycy to grupa ortodoksyjna, chociaż ich teologia i formy kultu pozostawały archaiczne. Szczególnie ważne było zachowanie przez nich pamiątek związanych z wydarzeniami ziemskiego życia Chrystusa, Jego śmiercią i Zmartwychwstaniem. Hieronim znal miejscowe tradycje wywodzące się z kręgów judeochrześcijańskich, chociaż w kwestiach prawowierności wiary był nieustępliwy ${ }^{14}$. Warto ponadto zwrócić uwagę, że Strydończyk rozróżnia wyraźnie „mesjasza judaistycznego" i Chrystusa Zbawiciela ${ }^{15}$.

Mimo szerokiego korzystania ze spuścizny Orygenesa w wyjaśnianiu ksiąg biblijnych, u Hieronima mniej wyraźne są wątki myśli chrystologicznej tego aleksandryjskiego autora. Refleksja Adamancjusza przeszła ewolucję od rozważań biblijnych i kerygmatycznych dotyczących osoby Zbawcy, do bogatych rozważań o charakterze ontologicznym i dogmatycznym. Obecność Orygenesa w panoramie teologii palestyńskiej można łatwo uzasadnić nie tylko jego pobytem w Cezarei Nadmorskiej przez dwie dekady, lecz również faktem, że jego myśl była natchnieniem dla teologii i życia duchowego w Ziemi Swiętej. Potwierdzają to dwie kontrowersje dotyczące Orygenesa i jego spuścizny, których początkowe akty rozegrały się na scenie palestyńskiej na początku $\mathrm{V}$ i w 1 . poł. VI wieku $^{16}$. Po epoce, na której piętno wycisnęła osobowość wielkiego Aleksandryjczyka, Palestyna będzie już gotowa, aby przemawiać własnym głosem w kwestiach chrystologicznych. Widać to już wyraźnie w nauczaniu Pawła z Samosaty ${ }^{17}$.

${ }^{11}$ Dziś uważa się, że ruch ten nie został założony przez samego Ebiona, ale miał innych fundatorów. Postać, od której sekta przyjęła nazwę, to jedynie najważniejszy jej przedstawiciel i ideolog.

12 Orygenes, opierając się na grze słów (Ebion - ubogi), ukazuje „ubóstwo” ebionitów w zakresie interpretacji duchowej (chrześcijańskiej) Pisma Świętego.

${ }_{13}$ Por. J. Daniélou, Teologia judeochrześcijańska, tłum. S. Basista, Kraków 2002, 339-340.

14 Hieronim mówi często o ,półżydach" i ,judaizujących". Współczesnych sobie milenarystów posądza o herezję ebionitów i sprzyjaniu „literze, która zabija”, por. In Isaiam 60, 1-3; 49. $14-18 ; 48,12 ; 66,20$.

${ }^{15}$ In Hiezechielem 16, 55; 40, 5-13. W tych fragmentach komentarzy biblijnych Hieronim używa słowa Christus, latynizując greckie okreslenie Christos.

${ }^{16}$ Por. E. Clark, The Origenist Controversy. The Cultural Construction of an Early Christian Debate, Princeton 1992.

17 Jego doktryna to kombinacja chrystologii o charakterze mądrosciowym i adopcjonizmu. Kontrowersję tę uznaje się za jedną z najważniejszych w Kościele przednicejskim, por. L. Perrone, 
W dziełach Orygenesa uderza głęboka i wszechobecna biblijność jego refleksji. Oznacza to, iż również chrystologia jest postrzegana w tym świetle. Mimo inklinacji spekulatywnych i wątków ontologicznych, które znajdują swoje ujście w jego systematycznym dziele De principiis $^{18}$, ma się do czynienia z chrystologią biblijną, a więc jest to jakby ciągła medytacja Słowa Bożego. Biblia jest „księgą Chrystusa”"19 , którego tajemnica głoszona przez Kościół stanowi klucz do zrozumienia zarówno Starego jak i Nowego Testamentu. Owo zrozumienie osiągają ci, którzy posiadają „zamysł Chrystusowy” (por. $1 \mathrm{Kor} 2,16)^{20}$.

We wstępie do De principiis Orygenes mówi o Chrystusie jako boskiej Mądrości istniejącej przed wiekami, razem z Ojcem² ${ }^{21}$ : to Jednorodzony Syn, działający w dziele stworzenia, objawienia i odkupienia. Historia jest połączona nicią dobroci Słowa, które ukazuje się ludziom i prowadzi ich do zbawienia. Stary Testament zawiera w sobie „typy" zapowiadające prawdę i spełnienie w Chrystusie. Typologia osiąga swój punkt kulminacyjny w osobie Jozuego, który już przez swoje imię obwieszcza tajemnicę prawdziwego Zbawiciela Jezusa Chrystusa ${ }^{22}$. Przybycie Jozuego do ziemi obiecanej oznacza zastąpienie Starego Zakonu Ewangelią. Orygenes nie ogranicza się wyłącznie do przypominania historii i odczytuje księgi mądrościowe oraz prorockie jako ogólną zapowiedź Chrystusa. Ponadto objawienie się zbawczych tajemnic nie zostało udzielone wyłącznie prorokom żydowskim, o czym świadczy proroctwo Balaama. Perykopa z Księgi Liczb (23-24) wzbudziła szczególne zainteresowanie Adamancjusza, była bowiem dla niego świadectwem podkreślającym powszechność zbawienia ${ }^{23}$.

$\mathrm{Na}$ wszelkie sposoby Orygenes stara się o zgłębienie tajemnicy Chrystusa, Boga - Człowieka. W egzegezie Psalmów Aleksandryjczyk posługuje się tzw. prozopologią ${ }^{24}$, co pozwala mu zwrócić uwagę na tajemniczą jedność bóstwa i człowieczeństwa $w$ osobie Zbawcy. W pewnym sensie zapowiada późniejsze formuły mówiące o „dwóch naturach w jednej osobie”. Komentując Ps 44

L'enigma di Paolo di Samosata. Dogma, Chiesa e società nella Siria del III secolo: prospettive di un ventennio di studi, CNS 13 (1992) 253-327.

18 Orygenes ujmuje doktrynę chrystologiczną w De principiis I 2 i II 6.

19 Por. M. Fédou, La Sagesse et le monde. Le Christ d'Origène, Paris 1994.

20 Por. J. Rius - Camps, El dinamismo trinitario en la divinisación de los seres racionales según Orígenes, Roma 1970, 378-382.

21 Por. De principiis I Praefatio, 4.

${ }^{22}$ Por. A. Jaubert, Origène. Homélies sur Josué, wstęp i przekład SCh 71, Paris 1960; J. Daniélou, Sacramentum futuri. Études sur les origines de la typologie biblique, Paris 1950, 212-215.

${ }^{23}$ Znaczenie Lb 23, 18 - 24, 24 w egzegezie Orygenesowskiej podkreśla M. Fédou, Christianisme et religions païennes dans le „Contre Celse” d'Origène, Paris 1988, 447-470.

${ }^{24}$ Por. M.J. Rondeau, Les commentaires patristiques du psautier (III'-V siècle), t. 2: Exégèse prosopologique et théologie (OCA 224), Roma 1985, 39. Autorka koncentruje się na Philocalia VII 1 i 2. 
Doktor aleksandryjski rozróżnia tytuły chrystologiczne i podkreśla, że określenia „Król” i „Pomazaniec” oznaczają Boga i człowieka ${ }^{25}$.

Wchodzi się tutaj w szeroki temat epinoiai, czyli „tytułów” lub „określeń” Chrystusa, łączący biblijną terminologię ze sformułowaniami ontologicznymi ${ }^{26}$. Ten charakterystyczny dla Orygenesa wątek nie prowadzi bynajmniej do minimalizowania kwestii wcielenia i jego znaczenia, jak później miało to miejsce u Euzebiusza z Cezarei. Aleksandryjczyk kładzie akcent na fakt, ze Chrystus był prawdziwym człowiekiem, który posiadał ciało, duszę i „ducha”"27. Stąd też pewne wyczulenie ze strony tego autora na aksjomat soteriologiczny bardzo popularny wśród późniejszych Ojców Kościola: quod non est assumptum, non est sanatum ${ }^{28}$. Zasada ta miała ważne konsekwencje, przede wszystkim przebóstwienie, stąd jej szerokie zastosowanie w późnej patrystyce i teologii bizantyjskiej.

Nie sposób pominąć delikatnej i kontrowersyjnej kwestii zgodności myśli Orygenesa z późniejszymi formułami dogmatycznymi. Oskarżenia wysuwane przez jego zajadłych przeciwników często nie znajdują pokrycia w faktach. Spojrzenie z perspektywy czasu pozwala dostrzec ogromny postęp $w$ teologii dokonany przez Aleksandryjczyka. Pojawily się ponadto przewartościowania, jak na przykład opinia $\mathrm{H}$. Crouzela, odnosząca się do subordynacjonizmu Orygenesowego. Ocena tego uczonego jest wyważona i ukazuje, że w dziełach Orygenesa elementy hierarchii Boskiej łączą się $\mathrm{z}$ akcentowaniem równości Osób w Trójcy ${ }^{29}$. Trudno jest również oskarżać Aleksandryjczyka o inspirowanie Ariusza lub tych dewiacji chrystologicznych, które nękały Kościól począwszy od V wieku. Orygenes wybrał drogę refleksji ontologicznej, idąc jednocześnie w stronę mistycyzmu, ponieważ odpowiadał mu dynamizm duchowy. Według Doktora aleksandryjskiego jedność Logos-sarx jest możliwa dzięki duszy Chrystusa ${ }^{30}$. Wobec tajemnicy Boga - Człowieka ${ }^{31}$, jedność duszy ze Słowem zabezpiecza pełne uczestnictwo człowieczeństwa Chrystusa w Jego Bóstwie. Orygenes używa popularnego porównania żelaza rozpalonego w ogniu: głęboka jedność między Bogiem a człowiekiem w Chrystusie prowadzi do tego, że mimo niewyrażalnej różnicy obu natur nie można ich rozdzielić. W ten sposób wyprzedza on zasadę communicatio idiomatum.

${ }^{25}$ Por. In Johannem I 28, 191-196.

${ }^{26}$ Por. J. Wolinski, Le recours aux šp...noiai du Christ dans le „Commentaire sur Jean” d'Origène, w: A. Le Boulluec - A. Dorival (ed.), Origeniana Sexta. Origène et la Bible. Actes du Colloquium Origenianum Sextum (Chantilly, 30 août -3 septembre 1993), Louvain 1995, 465-492.

${ }^{27} \mathrm{Na}$ ten aspekt zwraca uwagę A. Grillmeier, Christ in Christian tradition. From the apostolic age to Chalcedon (451), t. 2, London - Oxford 1975, 143.

${ }^{28}$ Twierdzenie to sformułowal w klasycznej formie dopiero Atanazy w IV wieku, lecz jego treść jest już obecna w myśli Orygenesa, por. Perrone, „Four Gospels, Four Councils”, s. 363.

${ }^{29}$ Por. H. Crouzel, L'image de Dieu dans la théologie d'Origène, StPatr 2 (1957) 194-201.

${ }^{30}$ Por. De principiis II 6, 3 .

31 Orygenes jest pierwszym, który używa tego określenia, por. Grillmeier, Christ in Christian tradition, s. 146. 
Dla Hieronima z pewnością było nie do przyjęcia nastawienie fundamentalistyczne do spuścizny Orygenesa. Widać to w fakcie, że stawia on ponad uprzedzenia wartość egzegezy orygenesowskiej ${ }^{32}$ i korzysta $z$ niej nawet wtedy, gdy początkowy entuzjazm względem wielkiego Aleksandryjczyka przeradza się w bezwzględną krytykę. Ze strony egzegety łacińskiego daje się jednak zauważyć starania, aby spekulacje alegoryczne nie zepchnęły na plan dalszy interpretacji dosłownej i historycznej. Pomaga w tym Strydończykowi perspektywa chrystologiczna w egzegezie tekstu biblijnego ${ }^{33}$.

Spójrzmy na IV wiek, w którym napotykamy pewną różnorodność w sformułowaniach chrystologicznych, jak to widać na przykładzie postaci Euzebiusza z Cezarei i Cyryla Jerozolimskiego. Obaj autorzy, mimo różnych punktów widzenia, poświadczają ciągłość myśli chrystologicznej w Palestynie tamtego okresu. Można wysnuć wniosek, że innowacje pojawiły się jako odpowiedź na nowe problemy. Jest to jednak prawda połowiczna, bowiem Euzebiusz i Cyryl reagowali $w$ sposób sobie właściwy na nową atmosferę polityczną i religijną, wywierającą swój wpływ na sformułowania w sferze dogmatycznej ${ }^{34}$.

Euzebiuszowi przyszło żyć w bardzo specyficznym momencie historycznym, na styku epoki prześladowań i imperium chrześcijańskiego zapoczątkowanego przez Konstantyna ${ }^{35}$. Metropolita Palestyny potrafił celnie wybierać dziedziny swojej twórczości i kultywował własne zainteresowania, o czym świadczą dzieła historyczne, apologetyczne, teologiczne i egzegetyczne. Cała spuścizna Cezarejczyka ukazuje zmianę atmosfery kulturowej i otwarcie się nowych horyzontów dla piśmiennictwa chrześcijańskiego. Teologia Logosu wypracowana przez niego wykazuje wpływ apologetów i szkoły aleksandryjskiej $^{36}$. Nie ma ponadto zasadniczej różnicy pomiędzy jego chrystologią przed soborem w Nicei i po nim. Euzebiusz ugruntował zasady teologii, których

32 Poprzez terminologię, taką jak: „cień”, „wizerunek”, „figura”, Hieronim mówi o rzeczywistości historycznej Starego Przymierza i wartości duchowej Nowego. W tym przypadku przechodzi z „cienia” do „prawdy”, z „zapowiedzi” do jej „wypełnienia się”.

${ }^{33}$ Rys chrystologiczny jest szczególnie mocno widoczny w całym Komentarzu do Izajasza, uważanym zresztą za najlepsze dzieło egzegetyczne Hieronima, por. S. Gozzo, De s. Hieronymi Commentario in Isaiae librum, „Antonianum” 35 (1960) 169, przypis 1, w którym autor cytuje opinię A. Penny.

${ }^{34}$ Kwestia ciągłości i nowatorstwa tych dwóch autorów jest widoczna w spojrzeniu na problem miejsc świętych Palestyny, por. P.W.L. Walker, Holy City, Holy Places? Christian Attitudes to Jerusalem and the Holy Land in the Fourth Century, Oxford 1990; R.L. Wilken, The Land called Holy. Palestine in Christian History and Thought, New Haven - London 1992; L. Perrone, „Sacramentum Iudeae” [Gerolamo, Ep. 46]: Gerusalemme e la Terra Santa nel pensiero cristiano dei primi secoli. Continuità e trasformazioni, w: A. Melloni - D. Menozzi - G. Ruggieri - M. Toschi (ed.), Cristianesimo nella storia. Saggi in onore di G. Alberigo, Bologna 1996, 460-464.

${ }^{35}$ Por. T.D. Barnes, Constantine and Eusebius, Cambridge 1981, 81-190.

36 O wpływach Orygenesa na Euzebiusza por. Ch. Kannengiesser, Eusebius of Caesarea, Origenist, w: H.W. Attridge - G. Hata (ed.), Eusebius, Christianity and Judaism, Detroit 1992, 435-466. Atmosferę teologiczną w Palestynie początku IV wieku opisuje L. Perrone, Eusebius of 
trzymał się także w zderzeniu z nicejskim homousios. Nawet pisząc dzieło historyczne mówi, że rozpoczyna „od przedmiotu niewątpliwie wznioślejszego i potężniejszego niż wszystko co ludzkie, to znaczy od «ekonomii» $\mathrm{i}$ «teologii» dotyczących Chrystusa"37.

W przypadku Euzebiusza ma się do czynienia $\mathrm{z}$ bardzo rozwiniętym subordynacjonizmem ${ }^{38}$. Swiadectwem tego nastawienia jest specyficzna terminologia, której używa biskup Cezarei. W oddawaniu czci Bogu „obowiązuje pewna kolejność: na pierwszym miejscu wymieniamy Ojca niebieskiego, Boga i Pana, który jest także Bogiem i Panem Drugiego z kolei, to jest Boskiego Slowa, drugiego Pana, panującego nad wszystkim" "39. Mimo tych inklinacji, metropolita Palestyny stara się wyrazić relacje Syn - Ojciec według świadomości teologicznej panującej w kręgach konserwatywnych Kościoła jego epoki. Wykazuje sporą rezerwę wobec sformułowania homoousios, lecz podobne nastawienie nie było obce i innym współczesnym mu autorom. Dostrzega się tutaj wyraźny konserwatyzm teologiczny. To być może spowodowało, że Euzebiusz starał się sprzyjać arianom, chociaż nie zawsze w sposób wyraźny. Dopiero objęcie stolicy biskupiej w Cezarei przez Akacjusza ${ }^{40}$ uczyniło z metropolii palestyńskiej punkt oparcia dla zwolenników arianizmu ${ }^{41}$. Niemal bezwzględne przywiązanie do myśli Orygenesa to kolejny dowód na konserwatyzm teologiczny, chociaż i tutaj Euzebiusz nie naśladuje niewolniczo swego mistrza i nie brak mu kreatywności ${ }^{42}$.

Bez wątpienia również zmiana sytuacji Kościoła rzutowała na charakter chrystologii Euzebiusza. Łatwo daje się zauważyć, że systematycznie odwołuje się on do triumfalistycznych obrazów proroctw związanych z ustanowieniem panowania Mesjasza i głosi chwałę cesarza, reprezentującego Logos na ziemi. Władca imperium jest powołany do tego, aby tworzyć więź pomiędzy światem a Synem Bożym ${ }^{43}$. Ta forma refleksji chrystologicznej, uwarunkowana niewątpliwie polityką, jest najbardziej charakterystyczną nowością wprowadzoną do chrystologii przez Euzebiusza.

Caesarea as a Christian Writer, w: A. Raban - G.K. Holum (ed.), Caesarea Maritima. A Retrospective after Two Millennia, Leiden 1996, 515-530.

37 Eusebius, HE I 1, SCh 31, 3. Euzebiuszowi chodzi o „dzieło” i ,istotę” Zbawcy.

38 Jest to ocena A. Grillmeiera (Christ in Christian tradition, s. 168). Rozwinięcie tej myśli można znaleźć tamże, s. 170-177.

${ }^{39}$ Eusebius, Demonstratio evangelica V 8, PG 22, $381 \mathrm{~A}$.

40 A kacjusz był znany jako mówca. Hieronim w Liście 119, 6 (CSEL 55, 452-454, Czuj III 9698), przytacza fragmenty niektórych jego dziel.

41 W czasach sprawowania posługi w Jerozolimie przez biskupa Maksyma (lata 333-348) arianie starali się zdobyć przewagę. Udało im się zjednać biskupa miasta świętego, a hierarchowie ariańscy uczestniczyli w konsekracji bazyliki Anastasis.

42 Por. Kannengiesser, Eusebius of Caesarea, s. 435-466.

${ }^{43}$ Por. przede wszystkim H.A. Drake, In Praise of Constantine. A Historical Study and New Translation of Eusebius' Tricennial Orations, Berkeley 1976. 
Metropolita Palestyny był uważnym obserwatorem dyskusji chrystologicznych swej epoki, co poświadcza Apologia Orygenesa, napisana wspólnie z jego mistrzem i późniejszym męczennikiem Pamfilosem ${ }^{44}$. W rejestrze oskarżeń Orygenesa na czoło wysuwają się problemy chrystologiczne, które dyskutowano w pół wieku po śmieci wielkiego Aleksandryjczyka i po potępieniu Pawła z Samosaty. Euzebiusz pomija jednak niektóre ważne elementy chrystologii Orygenesowej, jak uznanie duszy - pośredniczki (mediatrix) w osobie Zbaw$\mathrm{cy}^{45}$. Biskup Cezarei jest przedstawicielem rozwijającej się w IV wieku chrystologii typu Logos - sarx, której przeciwstawiano inny model wypracowany w okresie przedchalcedońskim: Logos-anthropos. Trudno mu jednak zarzucić apolinaryzm ante litteram, ponieważ zwraca uwagę na rozróżnienie natur w osobie Jezusa Chrystusa oraz wystrzega się terminologii i idei przemieszania natur, co było charakterystyczne najpierw dla apolinaryzmu, a później przynajmniej teoretycznie, dla monofizyzmu.

Cyryl Jerozolimski był bardziej katechetą i gorliwym duszpasterzem aniżeli teologiem. Jednak jego Katechezy odsłaniają bogactwo doktrynalne i duchowe. Jest tak mimo faktu, że katechezy Cyryla nie zawierają zbyt wielu oryginalnych twierdzeń teologicznych i obca jest im także wyszukana forma literacka, bowiem posługuje się on językiem prostym, bogatym w obrazy i porównania. Katechezy to odbicie codziennej działalności duszpasterskiej biskupa, dla którego Pismo Swięte i tradycja apostolska stanowią źródło myśli teologicznej. Pouczenia jerozolimskiego Katechety mają charakter chrystocentryczny. Prawda o Chrystusie stanowi w metodologii Cyryla zasadę jedności i centrum historii zbawienia, streszczonej $\mathrm{w}$ wyznaniu wiary ${ }^{46}$. Osoba Zbawiciela jest elementem scalającym i nadającym sens księgom biblijnym.

Cyrylowi nie było obce zagadnienie natury ludzkiej Syna Bożego ${ }^{47}$ oraz uznanie Chrystusa jako „prawdziwego Boga” z Boga ${ }^{48}$. Przy głoszeniu tez chrystologicznych biskup świętego miasta odwołuje się do świadectw pism prorockich uważając, że Żydzi nie ośmielą się zaprzeczyć ich autorytetowi. Przypomina przy tym, ze w tajemnicy osoby Chrystusa obie natury, boska i ludzka, w ich złączeniu i rozróżnieniu, są z sobą jak najściślej zjednoczone. W ten oto sposób Cyryl nawołuje, aby strzec się doketów i adopcjonistów, jak

${ }^{44} \mathrm{Na}$ temat tego dzieła por. J. Quasten, Patrologia, I, Casale Monferrato 1983 (reprint), 405-406.

${ }^{45} \mathrm{~W}$ sposób jednoznaczny Euzebiusz odrzuca istnienie duszy w Chrystusie polemizując z Marcelim z Ancyry, uważanym za wyznawcę poglądów sabeliańskich, por. De ecclesiastica theologia II 13-18 (passim).

${ }^{46}$ Znaczące jest to, że Cyryl nie posługuje się nicejskim pojęciem homousios, obawiając się użycia tego terminu w duchu sabeliańskim i zachowuje dystans wobec wszelkiej terminologii obcej Pismu Świętemu, por. Catechesis IV 8, XI 13, XV 9, XVI 4, PG 33, 465, 705, 880, 921.

${ }^{47}$ Cyryl mówi (Catechesis XII 26, PG 33, 757B), że „Ten, który stworzyl członki, nie wstydzi się $\mathbf{z}$ nich przyjąć ciała".

48 Por. Catechesis XI 14, PG 33, 708. 
również niebezpieczeństw doktryny manichejskiej. Jest to możliwe dzięki zachowaniu jedności wiary, gdyż „błąd ma różne formy, a prawda [tylko] jedno oblicze" ${ }^{, 49}$.

Do tych aspektów polemicznych należy dodać fakt przywoływania rzeczywistości „świętych pamiątek” w Ojczyźnie Chrystusa. W ten sposób biskup Jerozolimy wprowadza wiernych w sferę „chrystologii doświadczenia”, która ugruntowana jest także w sakramentach. Rozważania chrystologiczne Cyryla uwydatniają jeszcze wyraźniej aspekty konkretności nauki chrześcijańskiej. W kontekście „miasta świętego" i „Ziemi Świętej” świadectwa prawd wiary przeciwko poganom i Żydom nie ograniczają się jedynie do Biblii, lecz poparte są argumentami innego typu, to jest sanktuariami odwołującymi się do pobożności chrześcijan ${ }^{50}$. Rzeczywistość miejsc zbawienia sprawia ponadto, że zbawczy krzyż zaczyna zajmować główne miejsce w nauczaniu Cyryla i tworzy się prawdziwa „teologia krzyża”, ukazująca rzeczywistość odkupienia ${ }^{51}$.

Biskup jerozolimski podkreśla, że jeśli nawet ktoś starałby się zaprzeczyć prawdziwości cierpień Chrystusa, to już sama Golgota i relikwie Krzyża ${ }^{52}$ wytrącają mu z rąk argumenty, gdyż stanowią bezpośrednie świadectwa męki Pańskiej. Wyraźnie więc formułuje zachętę i pobudza do umiłowania „pamiątek materialnych”, spełniających tak ważną rolę w dziele pogłębiania wiary. Niewątpliwie dzięki Cyrylowi chrystologia palestyńska wkracza w sferę otwierającą nową epokę: rzeczywistość miejsc świętych i pielgrzymowanie do nich stają się nieodłącznymi elementami przyszłych rozważań chrystologicznych ${ }^{53}$.

Przypomniani autorzy (Orygenes, Euzebiusz i Cyryl) byli w większym lub mniejszym stopniu inspiratorami autora Wulgaty. Na polu egzegetycznym to Orygenes stał się najważniejszym z poprzedników Hieronima oraz wzorem filologa i egzegety. Strydończyk pozostał wierny metodzie wypracowanej przez Szkołę Aleksandryjską mimo swoich ataków na Rufina z Akwilei, biskupa Jerozolimy Jana i zwolenników Orygenesa podczas pierwszej fazy kryzy-

49 Tamże XVIII 1, PG 33, 1017.

${ }^{50}$ Por. tamże X 19, PG 33, 685, thum. W. Kania, BOK 14, 142: „Wiele jest na prawdzie opartych świadectw o Chrystusie. O Synu [...] świadczy święte drzewo, które do dziś się u nas widzi [...] świadczy Getsemani, które rozważającym nad tymi rzeczami pozwala wciąż jeszcze patrzeć na Judasza. Świadczy ta góra święta, Golgota. Swiadczy prześwięty grób i kamień, co dziś tam leży".

51 Por. tamże XIII 4, PG 33, 776, BOK 14, 187: „Jezus prawdziwie cierpiał za wszystkich ludzi. Krzyż nie był urojeniem, inaczej byłoby urojeniem i zbawienie. Smierć nie była grą fantazji, inaczej nasze zbawienie byłoby grą fantazji [...]. [Chrystus] został ukrzyżowany i nie zapieramy się tego. Raczej dumny jestem, iż o tym mówię. Gdybym chcial teraz tego się zaprzeć, sprzeciwiłaby mi się Golgota, w której pobliżu się znajdujemy; sprzeciwiloby mi się drzewo krzyża, którego cząstki rozeszły się już stąd po całym świecie".

52 Cyryl przypomina o nich także w Catechesis X 19.

53 Panoramę sporów chrystologicznych na terenie Palestyny kreśli L. Perrone, La Chiesa di Palestina e le controversie cristologiche, Brescia 1980. Obszerna bibliografia znajduje się na s. 17-32. 
su związanego z orygenizmem. Zetknięcie się z dziełami Adamancjusza wskazało drogę interpretacji duchowej tekstów prorockich o charakterze mesjańskim i Psalmów, a właśnie w tym przypadku łaciński pisarz i tłumacz okazał się jednym $z$ najlepszych uczniów Orygenesa ${ }^{54}$. Interpretacja duchowa zajmuje równoznaczną pozycję z rozważaniami o charakterze historycznym i polemicznym. W kontekście tych zależności należy rozpatrywać odniesienia do nowych wątków teologicznych w dziełach Strydończyka.

Wpływ Euzebiusza na chrystologię Hieronima był z pewnością minimalny i stanowił raczej kontynuację wierności Szkole Aleksandryjskiej. Autor Wulgaty korzystal $\mathrm{z}$ dzieła historycznego i topograficznego Euzebiusza, a ten ostatni z całą pewnością opierał się na niektórych opracowaniach Orygenesa, dotyczących nazw biblijnych i terminologii hebrajskiej. Około $390 \mathrm{r}$. Hieronim przetłumaczył na język łaciński dzieło Euzebiusza, mające służyć pielgrzymom do Ziemi Swiętej i znane powszechnie jako Onomastikon ${ }^{55}$.

Z kolei dzięki kaznodziejskiemu trudowi Cyryla Jerozolimskiego Hieronim mial już wytyczony szlak kontekstualizacji nauk ascetycznych głoszonych w Betlejem. Nie bez znaczenia było ponadto dowartościowanie miejsc ewangelicznych w nauczaniu doktrynalnym, jak również fakt, że teologia cyryliańska należała raczej do typu „najsztywniejszej prawowierności przednicejskiej na

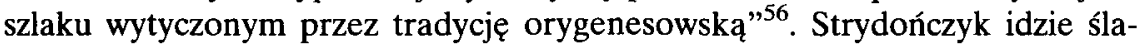
dem niektórych wcześniejszych autorów, w tym Atanazego, wyjaśniających niektóre kontrowersyjne wersety biblijne w odniesieniu do Chrystusa jako człowieka, akcentując naturę ludzką przyjętą przez Słowo ${ }^{57}$.

Rzymskie cechy charakteru sprawiają, że nasz autor widzi przede wszystkim konkretne implikacje założeń teologicznych. Podobne aspekty pojawiają się w jego rozważaniach biblijnych, dzięki którym słusznie przyznaje się Hieronimowi prymat wśród egzegetów łacińskich, chociaż nie stanął on nigdy na czele żadnej szkoły egzegetycznej. Spowodował to przede wszystkim brak kompleksowej zasady filozoficznej i teologicznej, chociaż tej wielkiej postaci

${ }^{54}$ Poświadczenie tej pracy stanowi komentarz do Psalmów, który większość badaczy uważa za przeróbkę homilii Orygenesa, thumaczonych przez Hieronima, por. V. Peri, Omelie origeniane sui Salmi. Contributo sull'identificazione del testo latino, ST 289, Città del Vaticano 1980.

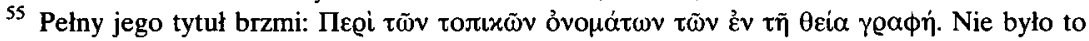
jednak jedyne thumaczenie Onomastikon, gdyż znana jest jeszcze jego wersja syryjska oraz inne thumaczenia. Dzielo biskupa Cezarei cytuje Prokopiusz z Gazy (VI wiek), a anonimowy artysta mozaikowej mapy z Madaby bez wątpienia posługiwał się Onomastikonem jako nieodłącznym przewodnikiem, por. E. Klostermann (hrsg.), Eusebius. Das Onomastikon der biblischen Ortsnamen, GCS 11/1, Leipzig 1904 [nowe wyd. Hildesheim 1966]; P. Thomsen, Palästina nach dem Onomastikon des Eusebius, „Zeitschrift des deutschen Palästina Vereins” 26 (1903) 145-188; M. Noth, Die topographischen Angaben im Onomastikon des Eusebius, tamże 66 (1943) 32-63; T.D. Barnes, The composition of Eusebius' Onomasticon, JTS 26 (1975) 412-415.

56 M. Simonetti, La crisi ariana nel IV secolo, Roma 1975, 209.

57 Atanazy snuje takie rozważania w Epistola ad Serapionem II 9. 
nie można odmówić wielostronności zainteresowań. W interpretacji Pisma Swiętego jest on eklektykiem, lecz chodzi tu o eklektyzm szeroki i przemyślany, który wybiera najlepsze elementy ze Szkoły Aleksandryjskiej i Antiocheńskiej. Nie sposób mu także odmówić bardzo wiernego kroczenia ścieżką prawowierności.

2. Między Biblią a „Credo”. W analizie chrystologii Hieronimowej stosunkowo łatwo oprzeć się na linearnych rozważaniach szczególnego rodzaju tekstu, jakim są Kazania o Psalmach ${ }^{58}$. Jest to dzieło niejednorodne, i chociaż znane jest pod imieniem Hieronima, stanowi parafrazę i thumaczenie komentarza Orygenesa do Psalmów ${ }^{59}$. W każdym jednak przypadku, te kazania wygłoszone w Betlejem ok. $400 \mathrm{r}$. do audytorium złożonego $z$ mnichów i mniszek, pielgrzymów i miejscowych chrześcijan, ukazują problemy, które brał sobie do serca autor Wulgaty, walcząc $\mathrm{z}$ herezjami trynitarnymi i chrystologicznymi będącymi wyzwaniem dla nauki Kościoła ${ }^{60}$. Homilie Hieronima stanowią wymowny przykład odnowionej chrystologii w kontekście miejsc świętych, do których był on niezwykle przywiązany.

Dla Strydończyka, podobnie jak dla Orygenesa, Biblia jest księgą przesiąkniętą prawdą o Chrystusie. Osoba Zbawcy stanowi centrum Starego i Nowego Testamentu $^{61}$. W pierwszym rzędzie „wszystkie ewangelie unaoczniają osobę ludzką [Chrystusa]"62. Natchnione slowa pozwoliły więc Hieronimowi na mocne podkreślenie człowieczeństwa Chrystusa, którego nierozłączne elementy to ciało i dusza ${ }^{63}$. Zbawiciel uważany jest również za głównego bohatera Psalmów. Dzięki temu przekonaniu Strydończyk stosuje egzegezę prozopograficzną, pozwalającą na rozszerzenie opinii na temat osobowości Boga - człowieka. W perspektywie trynitarnej Hieronim patrzy na relację Syna z Ojcem i Duchem Świętym jako na niezgłębioną tajemnicę, której nie obejmie ludzki intelekt, a jedynie wiara po-

${ }^{58} \mathrm{~W}$ drugiej części serii homilii poświęconych Psalmom badacze dostrzegają po prostu łacińskie thumaczenie dzieła Orygenesa. Jednak egzegeta laciński nie jest akrytyczny w stosunku do Adamancjusza i z pewnością wprowadzil w nich pewne zmiany, por. tekst $\mathrm{CCL} 78,353-447$; G. Coppa (ed.), Origene - Gerolamo. 74 omelie sul libro dei Salmi, Milano 1993, 26-32.

${ }^{59}$ Zależnosć rozważań Hieronima od Orygenesa ukazuje m.in. V. Peri, Omelie origeniane sui Salmi. Contributo sull'identificazione del testo latino, ST 289, Città del Vaticano 1980. Twierdzenie to zostało odrzucone przez P. Jay’a, Les „Tractatus in Psalmos”, w: M.C. Duval (ed.), Jérôme entre l'Occident et l'Orient. XVI Centenaire du départ de saint Jérôme de Rome et de son installation à Bethléem (Actes du Colloque de Chantilly, Septembre 1986), Paris 1988, 367-380.

${ }^{60}$ Panoramę sporów doktrynalnych Hieronima przedstawia por. B. Jeanjean, Saint Jérôme et l'hérésie, Paris 1999.

61 Por. Perrone, ,Four Gospels, Four Councils”, s. 379.

62 Tractatus in Ps 109, 1, CCL 78, 222: „Omnia Evangelia personant de persona hominis”.

63 Jest to nawiązanie do zasady Orygenesa, wg której dusza posługuje się ciałem, por. Contra Celsum VII 38. Ten punkt widzenia akceptuje również Euzebiusz z Cezarei, ale mówi wyłącznie o czlowieku, por. Preparatio evangelica VII 48. 
zwala na dostęp do niej ${ }^{64}$. Czytanie Pisma Swiętego to dla Strydończyka wsłuchiwanie się w głos Chrystusa - Oblubieńca ${ }^{65}$. Należy jednak podkreślić, że użycie określenia persona przez Hieronima nie jest jeszcze w pelni zdefiniowane i ugruntowane $\mathrm{z}$ powodu tendencji utożsamiania tego pojęcia $\mathrm{z}$ naturą, jak wynika z pojawiającego się w homiliach o Psalmach zwrotu ,assumptus homo" 66 . Autor Wulgaty nie zastosowal w pełni formuły lacińskiej mówiącej o „dwóch naturach w jednej osobie Chrystusa". Przyczyną takiego nastawienia była być może opinia Apolinarego, który mimo zaprzeczania obecności rozumnej duszy w Chrystusie, podkreślał jedność Boskiej i ludzkiej natury, stosując formułę ,,jednej natury wcielonego Logosu” ${ }^{67}$. Strydończyk używa określenia „natura” w sposób archaiczny $^{68}$. Tylko jeden z oskarżycieli papieża Damazego (pochodzenia żydowskiego) mówi o „dwóch naturach Jednorodzonego i Pierworodnego, boskiej i ludzkiej (quia Unigenitus et Primogenitus duae naturae sunt, divina et humana), lecz [stanowiących] jedną osobę (sed una persona)" ${ }^{\text {69 }}$.

Podobnie jak inni pisarze tamtego okresu, Hieronim z emfazą podkreśla tajemnicę zrodzenia Syna. Inspiracją łacińskiego egzegety jest prawdopodobnie polemika antyeunomiańska, prowadzona przeciwko błędnowiercom, którzy rozwinęli racjonalistyczne ujęcie problematyki trynitarnej ${ }^{70}$. Być może właśnie polemika $\mathrm{z}$ ugrupowaniem ariańskim sprawiła, że Strydończyk tak wydatnie podkreśla kult należny Chrystusowi. Z drugiej jednak strony nie uświadamia sobie $w$ pełni, że oskarżany przez niego Orygenes ${ }^{71}$ był wielkim czcicielem osoby Zbawcy.

Dla autora Wulgaty błędy doktrynalne to nie tylko wynik czysto ludzkich spekulacji, zastępujących prawdy objawione, lecz przede wszystkim niebezpieczny i trujący owoc niewlaściwej interpretacji Pisma Swiętego ${ }^{72}$. Tak jest w przypadku doktryny apolinarystycznej, której inicjator,

${ }^{64}$ Por. Tractatus in Ps 91, 6. W Tractatus in Ps 98, 5 Hieronim przeciwstawia postawę wiernych nastawieniu spekulujących „dialektyków”.

65 Por. Epistula 22, 25.

${ }^{66}$ U Hieronima pojęcie persona jest dosyć elastyczne, co zauważa M.J. Rondeau (Les commentaires patristiques du psautier, t. 2, s. 140-145).

${ }^{67}$ Por. Grillmeier, Christ in Christian tradition, I/1, s. 333-336. Podobne sformułowania w klasycznej postaci obecne są u Cyryla z Aleksandrii, tamże, I/2, s. 473-477.

${ }^{68}$ Gra słów w Tractatus in Ps 109, 1. W wymienionym fragmencie dostrzega się płynnosć pojęcia „osoby”, stosowanego przez Hieronima, por. Rondeau, Les commentaires patristiques du psautier, t. 2, s. 140-144.

${ }^{69}$ Fides Isaatis ex Judaeo 4, CCL 9, 343. Podobne znaczenie można przypisać wyrażeniu z Expositio in Canticum canticorum 12: „Quae unum corpus Christi, sicut et anima Christi una persona cum Verbo effecta".

${ }^{70}$ Ostra krytyka tych błędów doktrynalnych występuje w Tractatus in Ps 5, 11.

${ }^{71}$ Hieronim nie cofa się nawet przed określeniem Orygenesa jako „źródło Ariusza”, por. Epistula 84, 4, CSEL 55, 125. Podobnie w: Contra Joannem Hierosolymitanum 18, PL 23, 370A.

${ }^{72}$ Por. Commentarius in epistulam ad Galatas III 5, 19-21; Commentarius in epistulam ad Titum II 10-11. 
„podążając przeciwko Pismu Świętemu, twierdzi, że nasz Pan, Jezus Chrystus, przyjął niedoskonałą naturę, a nie, iż przyjął ją w całej swej pełni, aby tym samym zapewnić zbawienie duszy i ciała"73.

Łaciński polemista przenosi główny punkt sporu na bardziej znany mu teren egzegezy biblijnej. Nie należy się temu dziwić, bowiem Hieronim ukazuje się ze swej najlepszej strony komentując tekst skrypturystyczny, a nie przedstawiając wątków teologicznych opartych na spekulacjach filozoficznych, przede wszystkim neoplatońskich ${ }^{74}$.

Należy zwrócić również uwagę na fakt, że interpretacja chrystologiczna nie jest wyłączną domeną egzegezy tekstów mesjanistycznych. Bez odnośnika do Chrystusa, zapowiedzi i symbole Kościoła tracą swój szczególny charakter ${ }^{75}$. Czasami sens eklezjologiczny łączy się z chrystologicznym. Chrystus bowiem „wyzwala tych, którzy wyznają wiarę w niego i przebywają w Kościele"76.

Czerpiąc $z$ wniosków nicejskiego wyznania wiary, sformułowanego po długich i zaciętych bojach $\mathrm{z}$ arianami, Hieronim podkreśla wzajemną relację Ojca i Syna: w dynamice trynitarnej Syn zwrócony jest ku Ojcu, a Ojciec kieruje się ku Synowi, gdyż Obaj posiadają jedną naturę i stanowią nierozłączną jedność ${ }^{77}$. Wydaje się, że autor Wulgaty nie zaatakował w sposób kompleksowy heretyków jak Ojcowie z „pars Orientis”, lecz wyodrębnił najbardziej naglące problemy środowiska palestyńskiego. Twierdzenia Hieronima naświetlają sytuację epoki, a czynią to nie tyle przez odwołanie się do echa dyskusji trynitarnych, lecz w oparciu o wskazówki odnoszące się do ewoluującej ku dogmatowi Chalcedonu myśli chrystologicznej ${ }^{78}$.

3. Miejsca święte świadectwami wiary w Chrystusa. Łaciński egzegeta i tłumacz miał wiele powodów, aby zająć się szczegółowo kwestią Ziemi Świętej. Podkreślanie wartości miejsc świętych, przede wszystkim Betlejem, to niewątpliwie jeden z najbardziej oryginalnych elementów myśli autora Wulgaty. W tym punkcie nietrudno jednakże zauważyć pewną niekonsekwencję Hieronima, który początkowo był nastawiony entuzjastycznie do życia w Ziemi Świętej. Z czasem zaczął odnosić się $\mathrm{z}$ rezerwą do warunków życia monas-

${ }^{73}$ Epistula 93, CSEL 55, 156.

${ }^{74}$ Por. A. Tuilier, Le sens de l'Apollinarisme dans les controverses téologiques du IV siècle, StPatr 13 (1975) 305. Na temat bazy filozoficznej herezji IV wieku por. A.H. Wolfson, Philosophical implications of Arianism and Apollinarism, DOP 12 (1958) 3-28.

75 Por. Epistula 46, 3, CSEL 54, 332: „Ze względu na etymologię miasto [Jerozolima] jest figurą Chrystusa, który otrzymał imię «Pan Panów» i «Król królów» (por. Ap 19, 16)".

${ }^{76}$ In Ioelem 3, PL 25, 951 lub CCL 76, 198. Wspominany przez Psalmy Syjon należy identyfikować z niebiańską Jerozolimą, siedzibą Chrystusa, o której opowiadają apostoł Pawel i autor Apokalipsy.

${ }^{77}$ Por. przede wszystkim Tractatus in Ps 66, 5; 109, 3.

78 Por. Perrone, „Four Gospels, Four Councils”, s. 379. 
tycznego, rzecz jasna czyniąc wyjątek tylko dla ukochanego Betlejem. Oba punkty widzenia można pogodzić lub przynajmniej połączyć dzięki twierdzeniom wypowiedzianym w homiliach o Psalmach. Strydończyk pisze:

„Błogosławiony ten, kto nosi w sobie krzyż, zmartwychwstanie, miejsce Narodzenia Chrystusa i Jego Wniebowstąpienia! Błogosławiony, kto nosi Betlejem w swym sercu i w którym Chrystus rodzi się co dnia"79.

Według Strydończyka pejzaż miejsc świętych winien być coraz głębiej poznawany w swej konkretności, przedstawiany w sferze duchowej i przeżywany jako osobiste doświadczenie życia chrześcijańskiego. W tradycji łacińskiej jeszcze nie raz zwracano uwagę na pełnię człowieczeństwa wcielonego Słowa potwierdzoną śladami materialnymi ${ }^{80}$. Chociaż Hieronim nie stara się całkowicie uduchowić historii i topografii biblijnej, co podkopałoby konkretne więzi $\mathrm{z}$ miejscami świętymi ${ }^{81}$, jednak zwraca uwagę na to, że:

„Z miejsc Ukrzyżowania i Zmartwychwstania korzystają tylko ci, którzy niosą swój krzyż na każdy dzień i codziennie zmartwychwstają z Chrystusem. Ci wszyscy więc, którzy okazują się godnymi tak chwalebnego miejsca" ${ }^{22}$.

Wśród stronic tchnących autentycznym nabożeństwem do miejsc świętych warto wychwycić wspomniane wcześniej niekonsekwencje. Hieronim daje do zrozumienia, że w kręgach monastycznych obecność w ziemskiej Jerozolimie nie należała do rzeczy najważniejszych ${ }^{83}$. $\mathrm{Na}$ tym jednak autor Wulgaty nie

${ }^{79}$ Tractatus in Ps 95, 10, CCL 78, 154-155: „Felix qui crucem, et resurrectionem, et locum nativitatis $X p i s t i$, et locum ascensionis portat in pectore suo. Felix est qui Bethleem habet in corde suo, in cuius corde Xpistus cotidie nascitur".

${ }^{80}$ Czyni tak papież Leon Wielki zwracając się do biskupa Jerozolimy Juwenalisa, któremu przypomina on, że powinien przepowiadać z żarliwością prawdę o wcieleniu Słowa. Juwenalis winien wykorzystać bliskość miejsc świętych dla pożytku duszy i intelektu, por. Epistula 139, 2, PL 54, 1105: „Powinieneś umieć posługiwać się, o najdroższy bracie, najpewniejszymi dokumentami wiary katolickiej, stając w obronie przepowiadania ewangelistów przez bezpośrednie świadectwa dawane przez miejsca święte, w których przebywasz... O tym wszystkim mówi ci nieprzerwanie sam święty krzyż, obwieszcza to głośno kamień z grobu, w którym Pan leżał z powodu swego człowieczeństwa, ale z którego powstał swoją Boską mocą. Kiedy kierujesz się ku Górze Oliwnej, aby uczcić miejsce Jego wniebowstąpienia, czyż nie wydaje ci się, że brzmi w twych uszach głos anielski, który do zdumionych uczniów w chwili wstępowania Pana na wysokości, mówił: «Mężowie z Galilei, dlaczego stoicie i wpatrujecie się w niebo? Ten Jezus, wzięty od was do nieba, przyjdzie tak samo, jak widzieliście Go wstępującego do nieba» (Dz 1, 11)"; zob. I. Grego, San Leone Magno e la Terra Santa, „Asprenas” 32 (1985) 331.

${ }^{81} \mathrm{Na}$ podstawie listu Hieronima do Dardanusa można przypuszczać, że chociaż uduchowienie wizerunku Jerozolimy poszło daleko do przodu, nie bylo tak w przypadku calej Ziemi Świętej, por. Epistula 129, 1, CSEL 56, 162-164.

${ }^{82}$ Epistula 58, 3, CSEL 54, 531.

83 Jako przykład wymienia przede wszystkim Antoniego, pierwszego pustelnika, a następnie „grupy mnichów z Egiptu i Mezopotamii, Pontu, Kapadocji i Armenii”, dla których otworzyły się bramy raju. Nawet Hilarion, który był Palestyńczykiem widział Jerozolimę tylko przez jeden dzień (Epistula 58, 3. CSEL 54, 531). 
poprzestaje i przedstawia mało budujący obraz życia codziennego w Jerozolimie $^{84}$. Stolica Judei nie oferuje niczego szczególnego, a pobyt w niej mógłby okazać się nawet szkodliwy dla duszy. Należy naśladować świętych mnichów, którzy uciekali od zgiełku miasta i nie zwracali uwagi na ziemską Jerozolimęę ${ }^{85}$. Trudno dociec, czy jedyną przyczyną tego typu osądu i konfliktu opinii u Hieronima było uzasadnione rozgoryczenie, bowiem o takiej postawie zdecydowały okoliczności ${ }^{86}$. Strydończyk i jego wspólnota znaleźli się w oku cyklonu wywołanego kryzysem dotyczącym Orygenesa: zostali ekskomunikowani i zabroniono im wstępu do świątyń chrześcijańskich. Hieronim pamiętał o obecności „konkurenta”, to znaczy Rufina, na Górze Oliwnej, gdzie bez wątpienia często trafiali pielgrzymi z Zachodu po przybyciu do Palestyny.

Wiele stronic dzieł Hieronima świadczy jednak o dostrzeżeniu wartości miejsc świętych. Tak na przykład w miejscach ewangelicznych, można „kontemplować ślady Narodzin [Zbawcy], Krzyża i Męki [Pańskiej], które wydają się zupełnie świeże”87. Zapowiadał to już cały Stary Testament: „Prawo i cała rzesza proroków przepowiadali mękę Chrystusa" 88 . Strydończyk mówi wyraźnie o potrzebie oddania czci Chrystusowi „w tych miejscach, w których Ewangelia wcześniej niż gdzie indziej zajaśniała blaskiem z krzyża"89. Nie budzi więc zdziwienia fakt, że postrzegał on pobyt w Ziemi Świętej nie tylko jako przywilej, lecz i obowiązek, kierujący automatycznie ku potrzebie zgłębiania Pisma Świętego. Kontakt z miejscami świętymi był dla niego jako mnicha czynnikiem ułatwiającym naśladowanie Chrystusa i swoistym błogosławieństwem.

Dla Hieronima nie jest możliwe zupełne uduchowienie faktów i miejsc związanych z osobą Chrystusa Pana, gdyż to oznaczałoby oderwanie ich od rzeczywistości. Przesłanki te ukazują się bardzo wyraźnie, gdy łaciński egzegeta mówi o Betlejem, jako o miejscu nakłaniającym do dostrzeżenia w żłóbku głównego znaku chrześcijańskiej wiary ${ }^{90}$. Dla Strydończyka Bóg stał się człowiekiem z powodu miłości dla całej ludzkości i wybrał miejsce wśród ludzi prostych i ubogich ${ }^{91}$.

${ }^{84}$ Por. Epistula 58, 4.

${ }^{85}$ Por. omawiany już przykład mnichów wg Epistula 58, 3.

${ }^{86}$ Podobne uprzedzenia wobec pielgrzymek do Jerozolimy były znane innym autorom chrzescijańskim, o czym świadczy korespondencja Grzegorza z Nyssy. Nie należy jednak brać pod uwagę bezpośredniej zależności Hieronima od pism biskupa Nyssy, gdyż obaj Ojcowie Kościoła świadczą o podobnych odczuciach ogarniających teologów i pisarzy ascetycznych, którzy występowali przeciwko niektórym konkretnym aspektom pielgrzymek. Podróże w duchu religijnym i z Biblią w ręku zastąpiło masowe poszukiwanie kontaktu z relikwiami i miejscami świętymi, por. Grégoire de Nysse, Vie de Sainte Macrine. Introduction, SCh 178, Paris 1971, 65-66.

87 Epistula 47, 2, CSEL 54, 346.

88 In Malachiam IV 5. 6, CCL 76A, 941; por. również In Matthaeum III 17, 3.

${ }^{89}$ Epistula 46, 9, CSEL 54, 339..

90 Por. Perrone, „Four Gospels, Four Councils”, s. 383.

91 Por. Tractatus in Ps 131, 6. 


\section{POLEMIKA Z APOLINARYSTAMI}

Najbardziej charakterystyczny etap rozwoju chrystologii Hieronima związany jest $\mathrm{z}$ dyskusją, która wywiązała się wokół założeń apolinaryzmu². Kryzys związany z postulatami Apolinarego wybuchnął w latach siedemdziesiątych IV wieku, gdy kontrowersje ariańskie powoli dobiegały końca. Mimo faktu, że Hieronim pobieral nauki u Apolinarego, czuł się jednak bardzo mocno związany $z$ Kościołem rzymskim, przede wszystkim w kwestiach prawowierności ${ }^{93}$. Autor Wulgaty był pod niewątpliwym wpływem Ojców Kapadockich. Znał wypowiedzi papieża Damazego i Grzegorza z Nazjanzu, potępiające założenia Apolinarego. Formuły chrystologiczne przypisywane biskupowi Laodycei stały się z czasem niezwykle kontrowersyjne, nie tylko ze względu na osobę ich twórcy ${ }^{94}$. Tezy Apolinarego były znane i wyznawane w Palestynie pod koniec IV wieku ${ }^{95}$. Jednak wydaje się, ze to przede wszystkim fakty historyczne skłoniły tego autora do polemizowania z Dionizym Aleksandryjskim, bowiem chodziło raczej o poglądy milenarystyczne pojawiające się w Egipcie i zwalczane przez małoazjatyckiego mistrza Hieronima ${ }^{96}$.

Autor Wulgaty, tak silnie podkreślający konkretne aspekty wcielenia Słowa, nie mógł zignorować tez Apolinarego, bowiem wprowadził on „ryzykowne i niejasne spekulacje dotyczące wcielenia" ${ }^{, 97}$. Odpowiedź Hieronima opiera się na założeniach tradycyjnej doktryny dotyczącej Jezusa Chrystusa, prawdziwego Boga i człowieka. Strydończyk rozwija swoje rozważania w celu precyzyjniejszego określenia człowieczeństwa Chrystusa, lecz bierze również pod uwagę, w jaki sposób dwie natury łączą się w Nim. W pewien sposób ma się do czynienia z pierwszym i nieco niepewnym założeniem przyszłego Soboru Chalcedońskiego, ponieważ autor łaciński kieruje swoje zainteresowania ku ,jedności osoby". Dochodzi do tego twierdzenie odrzucające oskarżenie apolinarystów, według których przyjęcie dwóch kompletnych natur w Chrystusie może doprowadzić do uznania "dwóch Synów"98. Owo sformułowanie przeczy pierwotnym założeniom kręgu tak zwanej „Szkoły Antiocheńskiej”99.

92 Por. M.C. Paczkowski, Girolamo e la polemica antiapollinarista, „Antonianum” 79 (2004) 473-504.

93 Por. Epistulae 84, 7; 119, 11.

94 Miały na to wpływ kontakty Hieronima nie tylko ze srodowiskiem teologicznym Rzymu, ale również z Kapadocczykami i Dydymem Ślepym, por. Rondeau, Les commentaires patristiques du psautier, t. 2, s. 152-155.

95 Znamienna jest relacja Grzegorza z Nyssy, por. Epistula 3, 24-26, PG 46, 1016-1024, thum.

T. Sinko: Sw. Grzegorz z Nyssy, Wybór pism, Warszawa 1963, 230-237.

96 Dydym czyni to w dziele $O$ obietnicach.

97 Basilius, Epistula 265, 2, PG 32, 985. Stowa te biskup kapadocki kieruje do biskupów Egiptu na wygnaniu.

98 Por. Tractatus in Ps 109, 1, CCL 78, 222; Epistula 120, 9, CSEL 55, 498; Commentarius in Zachriam II 6; Commentarius in Hieremiam III 52. 
,[Zbawiciel] jako człowiek zostaje ukrzyżowany, a jako Bóg doznaje chwały [...]. Mówimy to, nie dlatego, że wierzymy, iż Bóg i człowiek to dwie różne rzeczywistości, czyniąc z Syna Bożego dwie osoby, jak to utrzymuje w sposób nierozumny nowa herezja. Dla nas jeden i ten sam Syn Boży jest również «synem człowieczym», wszystkie wypowiadane przez Niego slowa w części odnosimy do chwały jego boskości, a w części do naszego zbawienia"100.

Hieronim formułuje tezę chrystologiczną, bazując na poszukiwaniu złotego środka pomiędzy monofizyzmem ariańsko-apolinarystycznym a chrystologią o rysach rodem $\mathrm{z}$ dawnych kręgów adopcjonalistó $w^{101}$. Łaciński autor używa określenia „osoba” (persona) w sposób niezbyt ścisły i ugruntowany. Jest to związane $\mathrm{z}$ tendencją utożsamiania tego terminu $\mathrm{z}$ koncepcją natury, jak na to wskazuje użycie go w odniesieniu do assumptus homo ${ }^{102}$. Wyłuskać stąd można pierwsze trudności w formułowaniu dogmatu o tajemnicy Chrystusa, co zajmie na długi czas teologów chrześcijańskich, w tym również autorów wywodzących się z Palestyny.

Uznanie przez Hieronima pełni człowieczeństwa w Chrystusie zakłada nie tylko obecność duszy i ciała, jak w każdej istocie ludzkiej, lecz również istnienie w Nim ludzkich odczuć i odruchów ${ }^{103}$. Jest to wizja nie tylko niezwykle konkretna, ale i na wskroś nowoczesna. Autor Wulgaty nie ogranicza się do prostej deklaracji prawowierności wobec apolinaryzmu, lecz potrafi, dzięki odnośnikom do aspektów psychologicznych Psalmów, podkreślić w osobie Zbawcy ludzkie uczucia ${ }^{104}$.

Na zarzuty „nowej herezji”"105 i ,judaizmu heretyckiego" ${ }^{106}$ Hieronim odpowiada niemal wyłącznie w kontekście egzegetycznym. Jest to zrozumiałe, bowiem

99 Por. Perrone, „Four Gospels, Four Councils”, s. 380.

100 Epistula 120, 9, CSEL 55, 497-498 : „Crucifigitur ut homo, glorificatur ut Deus [...]. Haec dicimus, non quod alium Deum et alium hominem esse credamus et duas personas faciamus in uno filio Dei, sicut nova heresis calumniatur, sed unus atque idem filius Dei et filius hominis est et, quicquid loquitur, aliud referimus ad divinam eius gloriam, aliud ad nostram salutem".

101 Por. Grillmeier, Christ in Christian tradition, s. 400-401.

102 Por. Tractatus in Ps 109, 1.

103 Ten wątek refleksji jest obecny u Ojców greckich. Bazyli Wielki twierdzi: „Chrystus zapłakał (por. Łk 19,41), aby dać właściwy kierunek temu tak bardzo uczuciowemu i nędznemu faktowi [widocznemu] u tych, którzy są skłonni do narzekań i lubią płakać... Jasno widać więc to, że płacz Pana nie był uczuciowy, lecz pouczający" (De gratiarum actione 5, PG 31, 228). Kapadocczyk mówi również o „trudach Pana" jako człowieka" (tamże 5). Natomiast Jan Zlotousty przekonuje, że Chrystus „ukazuje naszą ludzką naturę: płacze i wzrusza się... Dlaczego Ewangelista powtarza przy tej okazji, że zapłakał i wzruszył się w duchu? To dlatego, abyś ty zrozumiał, że On rzeczywiście przyoblekł naszą naturę" (In Joannem hom. 63, 1-2, PG 59, 349-352).

104 Por. przede wszystkim G. Furlani, Studi Apollinaristici II: I presupposti psicologici della cristologia di Apollinare di Laodicea, „Rivista trimestrale di studi filosofici e religiosi” 4 (1923) 129-146. 105 Wyrażenie użyte w Epistula 120, 9, CSEL 55, 498 oraz w Tractatus in Ps 15, 9-10, CCL 78, 379-384.

106 Por. In Danielem III 9, 24. 
tezy chrystologiczne apolinarystów opierały się chociażby na egzegezie Flp 2,6-8. Ten hymn Pawłowy miał być potwierdzeniem, że Chrystus nie był w pełni człowiekiem, ponieważ posiadał jedną naturę i był jedna osobą ${ }^{107}$. Jedność osoby Zbawcy sprawia, że „nie dzieli się ona na dwie części ${ }^{108}$, ponieważ ani ciało nie jest naturą samą w sobie, ani bóstwo nie stanowi odrębnej natury we wcieleniu, lecz jako człowiek, jedną naturę stanowi również Chrystus, który «stał się podobny do ludzi»" 109 . Hieronim nie czuł jednak potrzeby, aby w sposób systematyczny obalić zasady tej interpretacji ${ }^{110}$, która z pewnością była mu znana, bowiem stosuje Flp 2, 6-8 w serii cytatów, których egzegeza miała rysy wyraźnie antyapolinarystyczne ${ }^{111}$. Nawiązanie jednak do uczuć i ludzkich odruchów Zbawcy to wyraźna oznaka twierdzeń chrystologicznych o zabarwieniu antiocheńskim: Logos nie staje się po prostu „ciałem”, lecz przyjmuje w całej pełni ludzką naturę. Dla mnicha z Betlejem słabość ludzka przyjęta przez Zbawiciela łączy się ściśle z Jego wcieleniem i z przyjęciem „podobieństwa do sługi”" ${ }^{112}$.

Przy innych okazjach Hieronim odpowiada na zarzuty apolinarystów przypominając o złożonej strukturze bytu ludzkiego (homo compositus) ${ }^{113}$. W komentarzu do Ps 108,31 Strydończyk opisuje odczucia Chrystusa w czasie męki. Odwołując się do tekstu Mt 26, 38 autor dostrzega ogromny smutek, który ogarnąl Chrystusa. Fakt, że Zbawiciel doznaje takich odczuć, jest dla autora łacińskiego dowodem, że posiadał On duszę, która cierpiała z powodu udręk i pragnień ciała, chociaż nie skłaniała się ku złu i grzechowi:

„Jeśli więc zacząl odczuwać smutek i doświadczył bólu, posiadał więc zdolność odczuwania lub czucia. W rzeczywistości bowiem ból zakłada wrażliwość. Jeśli

107 Ważne pod tym względem są opinie Hieronima w Epistula 120, 9, CSEL 55, 497-498: „Crucifigitur ut homo, glorificatur ut Deus [...]. Haec dicimus, non quod alium Deum et alium hominem esse credamus et duas Personas faciamus in uno Filio Dei, sicut nova haeresis calumniatur, sed unus atque idem Filius Dei et filius hominis est, et quidquid loquitur, aliud referimus ad divinam eius gloriam, aliud ad nostram salutem, por. Grillmeier, Christ in Christian tradition, I/2, $\mathrm{s}$. 401; podobne opinie w: Tractatus in Ps 109, 1; Commentarius in Zachariam 2, 6; Commentarius in Hieremiam 3, 52, zob. wyżej n. 97.

${ }^{108}$ Najwyraźniej Hieronimowi chodzi tu o odrzucenie oskarżenia o wprowadzaniu „dwóch Synów", por. Apollinaris, Epistula ad Dionysium I 2 (CPG II 3669).

109 Por. Epistula ad Dionysium I 2; E. Bellini (teksty oryg., wstęp, przypisy i tlum. wh.), Su Cristo. Il grande dibattito nel quarto secolo, Milano 1977, 101. Znaczenie tego fragmentu podkreśla G. Voisin, L'apollinarisme. Étude historique, littéraire et dogmatique sur le début des controverses christologiques au IV siècle, Louvain - Paris 1901, 328-329.

110 Podobne nastawienie pojawia się u św. Augustyna, który w interpretacji Flp 2, 6-8 wykazuje, że tezy apolinarystów nie musiały być odpierane przy każdej okazji, por. Augustinus, De diversis quaestionibus 73, 1.

111 Por. In Abacuc II 3, 4, CCL 71A, 624, gdzie Hieronim cytuje obok Flp 2, 6-8 również Mt 26, 38-39.

112 Por. Tractatus in Ps 15, 7; 15, 5, CCL 78, 373, 377.

113 Por. np. Tractatus in Ps 15, 9-10. Antyapolinarystyczny charakter tej interpretacji podkreśla Rondeau, Les commentaires patristiques du psautier, t. 2, s. 145-147. 
więc [heretyk] chciałby nam powiedzieć: Nie mówimy, że posiadał On zdolność odczucia, aby nie wydawało się, iż był w Nim obecny grzech; odpowiemy mu: [Chrystus] miał lub nie, takie ciało, jak my? Jeśli odpowiedzą, że je posiadał, powiemy: miał również odruchy naszego ciała. Każdy rozumie to, co mówię. Jeśli zaprzeczaliby również temu, że posiadał odruchy lub skłonności cielesne ${ }^{114}$, powiemy [wtedy], że nie miał ciała. Mówimy natomiast: posiadał On prawdziwe ciało podobne do naszego, nie miał jednak grzechu ciała. W taki sam sposób posiadał prawdziwą duszę, lecz nie miał grzechu duszy" "115.

Ten punkt widzenia oparty jest na postulacie soteriologicznym: człowiek, złożony z duszy i ciała, nie mógłby być zbawionym, jeśli Chrystus nie posiadałby ciała i duszy ${ }^{116}$ :

„Wyznajemy więc, że posiadał On prawdziwe ciało i prawdziwą duszę. Jeśli bowiem Pan nie posiadałby tego wszystkiego, co jest właściwe dla człowieka, nie odkupiłby go. Jeśli przyjąłby ciało, a nie duszę, zbawiłby więc ciało a nie duszę. My jednak głosimy, że została zbawiona raczej nasza dusza aniżeli ciało. Ponieważ Pan przyjął ciało i duszę, aby zbawić jedno i drugie, uwalniając całego czlowieka stworzonego. Jeśli więc tamci utrzymują, że Pan nie przyjął zdolności odczuwania (czyli nous) ${ }^{117}$, aby nie grzeszyć, myślą, iż ten kto posiada ludzkie zdolności odczuwania i przyjmowania ${ }^{118}$, nie jest w stanie nad nią [duszą] panować"119.

114 Hieronim znal z pewnością wywód Cycerona dotyczący „odruchów” ludzkich (passiones), por. Tusculanae disputationes IV 6; zob. E. Giovannetti, Cicerone. Le Tusculane, t. 2, Cernusco sul Naviglio 1947, 28-31; por. również H. Ab Arnim, Stoicorum veterum fragmenta, t. 3, Stuttgart 1964, 431-432; M. Pohlenz, La Stoa. Storia di un movimento spirituale, t. 1, Firenze 1978, 285-303.

115 Tractatus in Ps 108, 31, CCL 78, 220-221: „Si ergo habuit tristitiam, si habuit dolorem, ergo habuit et sensum: nam sensus dolor est. Si ergo vuolverint nobis dicere: propterea non dicimus eum habuisse sensum, ut non videatur habere peccatum; nos illis respondeamus: habuit corpus sicut et nos, aut non habuit? Si dixerint, habuit, respondeamus illis: ergo habuit et passiones corporis nostri. Intellegit unusquisque quod dico. Si autem negaverint eum habuisse passiones aut libidines corporis, ergo dicimus illis, quod nec corpus habuit. Et nos dicamus illis: sicut corpus habuit verum sicut et nos, et non habuit peccatum corporis; ita et animam veram habuit, et peccatum animae non habuit".

${ }^{116}$ Zasada ta, o wyraźnym wydźwięku antyapolinarystycznym, bazuje na koncepcji antropologicznej pochodzącej od Arystotelesa: człowiek składa się z duszy i ciała, por. Rondeau, Les commentaires patristiques du psautier, t. 2, s. 146-147.

117 Pojęcia sensus i voṽ s są dla Hieronima równoznaczne, por. Rondeau, Les commentaires patristiques du psautier, t. 2, s. 151. Warto przypomnieć, że autorzy tumaczą voū jako sensus począwszy od Tertuliana.

118 Ambroży z Mediolanu podkreśla, że Chrystus posiadał anima i sensus, lecz nie podlegał żadnemu czysto ludzkiemu pragnieniu, por. De incarnationis Dominicae sacramento VII 69.

${ }^{119}$ Tractatus in Ps 108, 31, CCL 78, 221: „Nos ergo confiteamur verum corpus eum habuisse ac veram animam. Si enim non suscepit Dominus cuncta quae hominis sunt, non saluavit hominem. Si autem suscepit corpus, animam autem non suscepit: ergo corpus salvavit, animam autem non salvavit. Nos autem volumus magis salvari animam nostram quam corpus. Suscepit ergo Dominus et corpus et animam, ut utrumque salvet, ut perfectum hominem salvet, sicut eum et condidit. Si ergo dicunt illi, quia ideo Dominus non accepit sensum, ut non peccaret, et hoc putant quod quicumque sensum habuerit humanum, vincere eum non potest"; Również Ambroży mówi 
Myśl podsumowująca ostatnią wypowiedź zdradza mnicha, dla którego panowanie nad popędami ciała i słabością ducha stanowiło klucz do zdobywania doskonałości. Temu właśnie elementowi należy przypisywać, że Hieronim nie obawia się używania szokującej terminologii w odniesieniu do Zbawcy, mówiąc o Jego passiones et libidines corporis. Nad wszystkim jednak króluje ostateczne zwycięstwo Pana. Apolinaryści pozbawiają Chrystusa tego triumfu i zubażają ludzkość, która w nim uczestniczy. Hieronim podziela troskę apolinarystów o podkreślenie bezgrzeszności Chrystusa ${ }^{120}$ i dochodzi do podobnych wniosków. Swoje konkluzje zamienia jednak w oręż przeciwko nim: Zbawiciel nie popełnil grzechu nie dlatego, że jego natura ludzka była niepełna, lecz ponieważ go odrzucil $^{121}$. W psychice Chrystusa uczucia i doznania nigdy nie dominują, lecz pozostają wyraźnymi znamionami prawdziwości Jego człowieczeństwa ${ }^{122}$.

Wydatne podkreślenie zbawienia duszy to charakterystyczny rys w rozważaniach Strydończyka. W Komentarzu do Ewangelii Mateusza ${ }^{123}$ nakreśla on precyzyjniejszy obraz tych rysów Zbawcy, rozpoczynając od podkreślenia rzeczywistości wcielenia:

„Pan, aby ukazać prawdziwość swego wcielenia, rzeczywiście się smuci. Jednak, aby nie dopuścić, by niepokój uczucia zapanował w jego duszy, zasmuca się zanim rozpoczyna się męka. Jedno to smucić się, a drugie to zaczynać popadać w smutek. Pan zasmuca się nie z powodu obawy cierpienia, bowiem przyszedł, aby je odkupić [...], lecz zasmuca się nieszczęśliwym losem Judasza ${ }^{124}$ [...]. Jeśli więc heretycy widzą w tym smutku obawę przed nadchodzącą męką, a nie dowód umiłowania przez Zbawcę [nawet] ludzi idących na zatracenie, jak wyjaśnią słowa wypowiedziane przez Boga ustami proroka Ezechiela: «Dla tych wszystkich, którzy wzbudzili we mnie smutek» (Ez 16, 43 wg LXX)"? ${ }^{125}$.

Hieronim odwołuje się do pojęcia propassio lub antepassio (grecka $\pi \varrho \circ \pi \dot{\alpha} \theta \varepsilon \iota \alpha)^{126}$, mówiąc o zwykłych emocjach, które nie pozostawiają piętna w sferze woli ${ }^{127}$.

o obecności duszy ludzkiej w osobie Chrystusa w kontekście soteriologicznym, por. De incarnationis Dominicae sacramento VII 68-69.

${ }^{120}$ Kwestię tę rozwija S. Visintainer, La dottrina del peccato in S. Girolamo, Roma 1962, 64-66.

121 Czasami „propassio" może przywiesć do grzechu, por. Visintainer, La dottrina del peccato in S. Girolamo, s. 155, 173, 178.

122 Grzegorz z Nyssy dostrzega w Chrystusie ludzkie odruchy i pragnienia, por. Adversus Eunomium Ill 4, 27-29; W. Jaeger (ed.), Gregorii Nysseni opera: Contra Eunomium, t. 2, Leiden 1960, 137.

${ }^{123}$ Nie brak fragmentów Komentarza do Mateusza, który wyszedł spod pióra Apolinarego z Laodycei. Hieronim znał to dzieło, por. Commentarius in Matthaeum Prol.

124 Dla Teodora z Mopsuestii Zbawca „rozgniewał się z powodu zdrady Judasza, oszołomiony zepsuciem jego woli" (In Joannem XIII 21).

125 In Matthaeum IV 26, 37, CCL 77, 253-254 lub SCh 259, 252. Na temat Komentarza do Mateusza por. J. Steinmann, Hieronymus, Ausleger der Bibel, Köln 1961, 278-280.

126 To określenia uczuć Chrystusa przed Jego męką, por. In Matthaeum I 5, 28, SCh 242, 118 , przypis 45. Hieronim powraca do tych pojęć w Liście do Sawiny (Epistula 79), thumacząc jako antepassio greckie słowo $\pi \varrho \circ \pi \alpha ́ \theta \varepsilon\llcorner$. Wizję Hieronima analizuje Visintainer, La dottrina del 
Rozróżnienie pomiędzy „początkiem smutku” (incipere contristari) ${ }^{128}$, a jego trwaniem może wydać się sztuczne, ale Strydończyk kładzie akcent na objawy i przyczyny tego stanu w duszy Zbawcy, a otchłanią rozpaczy, w której pogrążają się ludzie ${ }^{129}$. Epizod w Ogrodzie Oliwnym świadczy o istnieniu duszy rozumnej w Chrystusie. Hieronim stawia kwestię bardzo jasno:

„Ci, którzy sądzą ${ }^{130}$, że Pan przyjął nierozumną duszę (inrationabilem [...] animam), niech wyjaśnią, jak teraz może On być smutny i doświadczać tej chwili smutku. Chociaż stworzenia pozbawione rozumu stają się smutne ${ }^{131}$, jednak nie znają one ani przyczyny, ani czasu trwania [owego smutku]"132.

Podobne wątki można spotkać w komentarzu do proroctwa Izajasza ${ }^{133}$, gdzie mnich z Betlejem podkreśla, że dusza Chrystusa odczuwała żal z naszego powodu $^{134}$ :

peccato in S. Girolamo, s. 96-97. Użycie słowa $\pi \varrho o \pi \alpha ́ \theta \varepsilon ı \alpha$ nie tylko wskazuje na erudycję Hieronima, lecz i na fakt, że adresatka listu znała grecki. P. Jay analizuje dokladniej kwestię znajomości greckiego przez mnicha z Betlejem, por. tenże, Jérome auditeur d'Apollinaire de Laodicée à Antioche, REAug 20 (1974) 38-39.

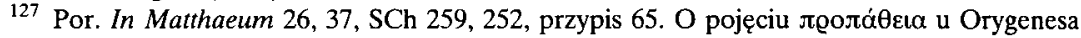
por. przede wszystkim Selecta in Ps 4, 5, PG 12, 1141D. Poruszana problematyka i zasada bezgrzeszności Chrystusa wykazują wyraźną zależność Hieronima od Dydyma. Por. Rondeau, Les commentaires patristiques du psautier, t. 2, s. 160-161.

${ }^{128}$ Sformułowanie to podkreśla Grillmeier, Christ in Christian tradition, I/2, s. 402. Orygenes jest zdania, że ,jeśli [...] ktoś, broniąc cierpień ludzkich, podaje nam, że i sam Jezus się smucil, niech posłucha, że Ten, który «jest doświadczony we wszystkim na nasze podobieństwo $\mathrm{z}$ wyjątkiem grzechu» (Hbr 4,15), nie zasmucil się smutkiem samej męki, lecz zgodnie z naturą ludzką znalazł się tylko na samym początku smutku i trwogi" (In Matthaeum commentariorum series 90, GCS 38, 206.

${ }^{129}$ Orygenes powołuje się na Mk 14, 33, aby wyjaśnić sens Mt 26, 37, por. In Matthaeum commentariorum series 90, GCS 38, 205-207: „Nie powiedziano: «Smucil się i odczuwal trwogę”, lecz: «Począł smucić się i odczuwać trwogę». Duża bowiem różnica zachodzi między smucić sį̨ i począć się smucić [...]. Widząc [...] grożącą Mu walkę, która nie byla dla Niego «przeciw krwi i ciału» (Ef 6, 12), lecz przeciw tylu «królom ziemi», stojącym obok «i wladcom» zgromadzonym «razem przeciw» Niemu (por. Ps 2, 2), ilu nie było nigdy, «począł drżeć» (Mk 14,33), bądź «się smucié», nie więcej smutku bądź drzenia doznając, jak tylko początek. Nie napisano bowiem, że drżał bądź smucił się, lecz "począł drżeć» (Mk 14, 33) i "począł się smucié», kiedy też rzekł: «Smutna jest dusza moja aż do śmierci». Co wydaje się tyle znaczyć, jakby powiedział: «Zaznatem początku smutku, tak iz nie jest mi zupelnie obcy przedsmak smutku; nie na zawsze, lecz tylko aż do czasu śmierci jest on we Mnie, tak iż kiedy umrę dla grzechu (por. Rz 6, 10), umrę również dla całego smutku, którego tylko początek był we Mnie»”. Na temat „antepassio" Chrystusa wg komentarza do Ps odkrytego w Tourze (przede wszystkim In Ps 39 [40], 2), por. A. Gerché, La christologie du „Commentaire sur les Psaumes" dècouvert a Toura, Gembloux 1962, 148-199.

${ }^{130}$ Komentarz w wyd. CCL 77 mówi, że byé może chodzi o Apolinarego, por. tamże, s. 254.

131 Dla Bazylego odruch zmystowy jest rzeczywiście ludzki, gdy odnosi się do duszy, w przeciwnym razie należałoby mówić o odruchach o charakterze zwierzęcym (instynktownym i nierozumnym), por. Epistula 261, 3 .

${ }^{132}$ In Matthaeum IV 26, 38, SCh 259, 254.

${ }^{133}$ Egzegezę Hieronima do Księgi Izajasza przedstawia P. Jay, L'éxègese de saint Jérome d'apres son „Commentaire sur Isaie”, Paris 1985. 
"[To zrozumiałe], że również Jego dusza prawdziwie cierpiala za nas, aby nie uważano, iż w Chrystusie po części jest prawda, a po części kłamstwo"135.

Hieronim traktuje jednak tę kwestię z ostrożnością mówiąc o ,początku żałości", bowiem cierpienie nacechowane rozpaczą nie zwyciężyło Jego Osoby. Wszelkie cierpienie Chrystusa to jakby „naturalny stan” duszy i ciała, a nie wyjątek i wydarzenia wstrząsające Jego jaźnią. W ten sposób autor Wulgaty odcina się od podziałów dokonanych przez Epifaniusza z Salaminy, który rozróżnia w człowieku pragnienia „dobre” i „nierozumne”

Hieronim występuje przeciwko schematycznemu rozróżnieniu stanu grzechu człowieka oraz jego natury na płaszczyźnie fizycznej i ontologicznej. Mimo swego radykalizmu ascetycznego mnich $\mathrm{z}$ Betlejem nie identyfikuje natury ludzkiej $\mathrm{z}$ grzechem. $\mathrm{Z}$ drugiej jednak strony tylko wspólne działanie obu natur w Chrystusie, boskiej i ludzkiej, przynosi zbawienie ludzkości.

Obszerne i linearne wywody Apolinarego tylko okazyjnie stają się powodem krytyki Hieronima, który zaledwie ślizga się po powierzchni głębszych problemów chrystologii. Ma się jednak wrażenie, że polemika antyapolinarystyczna Strydończyka, to rozmowa głuchych. Specyficzny język Laodycejczyka posiadał podwójną funkcję: na płaszczyźnie ontologicznej i moralnej. Podobnie jak inni adwersarze biskupa Laodycei, również Hieronim w pełni tego nie zrozumial.

\section{CHRYSTOLOGIA NA USŁUGACH WIARY I DUCHOWOŚCI}

Pełne uznanie człowieczeństwa Zbawiciela miało dla Hieronima implikacje natury duchowej, chociaż nie zapomina on o liturgicznych aspektach kontemplacji tajemnicy wcielenia. Poświadcza tym samym, że w ożywczym strumieniu teologii będącej $\mathrm{w}$ nieustannym kontakcie $\mathrm{z}$ miejscami zbawienia powstały specyficzne obrzędy i celebracje, a niektóre święta liturgiczne nabrały nowego znaczenia. Proces tworzenia się liturgii nie mógł uniknąć konfrontacji z problematyką doktrynalną. Nie bez powodu w Homilii o Narodzeniu Pańskim

${ }^{134}$ Duszę uważano za naturalne centrum ludzkich odruchów i uczuć, por. A. Vogtle, Affect, RACh I 160-173.

135 In Isaiam 53, 5/7, CCL 73A, 590: „Ita et animam vere doluisse pro nobis, ne ex parte veritas, et ex parte mendacium credatur in Christo", por. Grillmeier, Christ in Christian tradition, $\mathrm{I} / 2, \mathrm{~s} .402$.

${ }^{136}$ Epifaniusz uważa, że tylko kierując się rozumem podąża się drogą godną człowieka. Z tego względu biskup Salaminy precyzuje, że Chrystus przyjął „dobre” pragnienia. „Rozumne więc były głód, pragnienie, zmęczenie, sen i brak sił po marszu, smutek, żałość i trwoga. To wszystko [...] ukazalo prawdę rzeczywistego objawienia się [Słowa] w ciele" (Adversus haereses 26, 7 oraz 77, 29, 4, PG 41, 341 oraz PG 42, 684. 
Strydończyk wspomina fakty dotyczące kontestacji daty święta Narodzenia Chrystusa. Przy tej okazji najpierw wytrąca broń $\mathrm{z}$ rąk powołujących się na starożytną tradycję i replikuje:

„Twierdzimy, że Chrystus dziś się narodzil, a następnie w czasie Epifanii odrodził się (tzn. został ochrzczony) ${ }^{137}$. Mówiąc, że urodzil się w czasie Epifanii, lączycie razem narodzenie i odrodzenie" $" 138$.

Takie połączenie świąt zaciemnia znaczenie chrztu Jezusowego. W kolejnych krótkich zdaniach Strydończyk opiewa prawdę Narodzenia, aby przejść do polemiki $z$ apolinarystami ${ }^{139}$. Autor Wulgaty zapowiada niełatwe i długie dyskusje, w wyniku których jedno $\mathrm{z}$ najważniejszych świąt zaczęto obchodzić w Palestynie jako osobną uroczystość z powodu kontrowersji chrystologicznych $^{140}$. Podstawę stanowiła potrzeba zaakcentowania narodzin Chrystusa jako człowieka w zestawieniu z Jego chwałą Syna Bożego. Wiele racji przemawia za tym, aby celebrację Narodzenia Pańskiego odłączonego od Epifanii uważać za konsekwencję soboru w Chalcedonie, popartego i propagowanego przez patriarchę Juwenalisa. Nie bez znaczenia była również obecność wiernych pochodzących $\mathrm{z}$ innych stron imperium. Praktyka była zresztą dosyć zróżnicowana, co poświadcza świadectwo Hieronima. Zastanawiając się jednocześnie nad sposobem zespolenia natury boskiej z ludzką, egzegeta laciński daje namiastkę przyszłych rozważań na Soborze Chalcedońskim.

W rozważaniach Hieronima, dzięki połączeniu chrystologii i eklezjologii, pojawia się ponadto odkupieńcza wartość krzyża Chrystusa ${ }^{141}$. Mnich betlejemski podkreśla również powszechność zbawienia, przywołując wizerunek Chrystusa, który wyciąga swoje ramiona jak opiekuńcze skrzydła nad całym światem $^{142}$. Krzyż stanowi jakby kolumnę, na której wspiera się cały Kościól ${ }^{143}$. Jest to motyw, którzy zauważyli i rozwinęli wcześniejsi autorzy chrześcijańscy, ale Hieronim znajduje swoją własną ścieżkę ku żarliwemu i szczeremu nabożeństwu do Jezusa, kontemplując Go w kruchości i pokorze człowieczeństwa. Można tutaj dostrzec chrystologię o zabarwieniu soteriologicznym, gdyż jak pisze jeden z tłumaczy dzieł Hieronima: „Krzyż i męka wzbudzają niezliczone refleksje homilety: wywyższony na krzyżu, Chrystus podnosi nas, wzniósł nas

137 Skrót myślowy nawiązujący do chrześcijańskiego ujęcia chrztu.

138 Homilia de Nativitate Domini, CCL 78, 528.

139 Hieronim odwohuje się do tradycyjnej doktryny o pełnym bóstwie i czlowieczeństwie Jezusa Chrystusa: „Urodził się na ziemi jako człowiek doskonały, czlowiek z krwi i kości (in terra nascitur homo perfectus, homo totus)" (tamże).

140 Por. Perrone, La Chiesa di Palestina e le controversie cristologiche, s. 56.

141 Por. tenże, ,Four Gospels, Four Councils”, s. 372.

142 Por. Tractatus in Ps 90, 4, CCL 78, 128: „In scapulis suis obumbrabit tibi: exaltabitur in cruce, extendet manus, et proteget nos".

143 Por. Tractatus in Ps 95, 10, CCL 78, 154: „Crux enim ipsius columna est generis humani: in ipsa columna aedificata est domus eius". 
aż do siebie i wywyższył do niebios; umarł, aby nam dać życie [...] Syn Boży umarl jak człowiek, aby ludzie posiedli życie"144.

Podkreślanie człowieczeństwa Chrystusa ma jednak większe znaczenie w duchowości niż w teologii autora Wulgaty. W związku z tym pisał F. Cavallera: „,[Hieronim] poświęcił się Jezusowi Chrystusowi poprzez wyłączne nabożeństwo: o Nim myśli, gdy odrzuca świat, patrzy na Niego, aby znaleźć umocnienie w trudnych chwilach, pamięta o Jego przykładach i poświęceniu, aby zachęcić dusze do hojności... Myśl [o Chrystusie] jest zawsze obecna, Jego miłość wznosi ku wyżynom wszystkie ofiary... Swięty Hieronim wstępuje na najwyższe szczyty bezinteresownej miłości i tam jest wiernym echem tego, który głosił, że nic nie mogło odłączyć go od miłości Chrystusowej" ${ }^{145}$. U mnicha $\mathrm{z}$ Betlejem nie brak przykładów modlitw skierowanych bezpośrednio do Zbawcy, a w szkole swoich poprzedników „nabożeństwo do Chrystusa stało się centrum jego życia wiary" $" 146$.

Dla Hieronima zarówno oratio jak i lectio to dialog z Chrystusem ${ }^{147}$. Na podstawie wątków biblijnych nawiązuje do teologii przemienienia. Komentując tekst Izajasza, dostrzega Chrystusa „wzgardzonego [...] i poniżonego, gdy zawieszono go na krzyżu"148. Boskość Zbawiciela objawiła się na krzyżu poprzez niezwykłe zjawiska towarzyszące Jego śmierci: trzęsienie ziemi i zaćmienie słońca. Podobne znaczenie miały cuda podczas publicznej działalności Chrystusa. Blask i ukryty majestat Syna Bożego to nierozłączne aspekty biblijnego wizerunku Chrystusa. Podkreśla to Komentarz do Ewangelii Mateusza:

„Z pewnością ten sam blask i ukryta chwala Boża, jaśniejące także na Jego ludzkim obliczu, były zdolne do pociągnięcia ku sobie każdego, kto na Niego spojrzał" ${ }^{149}$.

Hieronim łączy w tych rozważaniach obraz Chrystusa cierpiącego i dotkniętego boleścią, co było motywem okresu prześladowań chrześcijaństwa, z obrazem chwalebnego Pantokratora z bazylik paleochrześcijańskich. Inspiracją Strydończyka była również apokryficzna Ewangelia Nazarejczyków ${ }^{150}$, której daje on własną interpretację. Strydończyk podkreśla chwałę Chrystusa mówiąc, że:

„[On] - najwyższy kapłan, obejmuje władzę, odziewa się w białe szaty i przyjmuje godność królewską, zakłada Kościół i wznosi duchową Jerozolimę"151.

144 Por. Coppa (ed.), Origene - Girolamo, s. 40-41.

145 Cytowany przez Grillmeiera w: Christ in Christian tradition, s. 402-403; por. F. Cavallera, Saint Jérome et la vie parfaite, RAM 2 (1921) 110.

${ }^{146}$ K. Baus, Das Gebet zu Christus beim heiligen Hieronymus, „Trierer Theologische Zeitschrift" 60 (1951) 188.

${ }^{147}$ Por. M. Maritano, /l Lector nel "Commento al vangelo di Matteo" di Girolamo, w: S. Felici (ed.), Esegesi e catechesi dei Padri, Roma 1994, 54-55.

148 In Isaiam XIV 53, 5/7, CCL 73A, 591.

149 In Matthaeum II 9, 9, PL 26, 56A.

150 Por. Evangelium Nazareorum 129, 2.

151 Tractatus in Ps 15 (series altera), 8, CCL 78, 379. 
Jednocześnie w perspektywie antyapolinarystycznej Strydończyk podkreśla prawdę o zstąpieniu Chrystusa do piekieł (descensus ad inferos). Jest to echo dyskusji nad Credo, które rozgorzały na przełomie IV i V wieku. Kwestię odnoszącą się do descensus ad inferos rozwiązano według znaczenia dosłownego tego twierdzenia, przyjmując tym samym punkt widzenia judeochrześcijan $^{152}$. Według opinii naszego autora Chrystus nie pojawił się w Otchłani jako „Bóg - Słowo lub jako człowiek złożony w swej naturze ${ }^{153}$, lecz do piekiel zstąpiła jego dusza (anima descendit ad inferos)" 154 . Odwołanie się do tradycyjnych doktryn pozwala na wskazanie, iż dusza Chrystusa nie była pozbawiona żadnej ze swoich funkcji, nawet gdy odłączyła się od ciała, aby uwolnić z Otchłani sprawiedliwych. Podobny wątek można dostrzec w interpretacji 15 Psalmu ${ }^{155}$ :

„Pan posiadal ciało i duszę: ciało zostało złożono $\mathrm{w}$ grobie ${ }^{156}$, a dusza zstąpiła do piekiel. $\mathrm{Z}$ tego [wynika], że ciało bez duszy było doskonałe, tak jak dusza bez ciała była doskonała i nie pozbawiono ją żadnej z funkcji naturalnych, które normalnie posiada, za wyjątkiem grzechu"157.

Widać, że w obronie pełnego człowieczeństwa w Chrystusie Hieronim posuwa się bardzo daleko. Funkcje duszy Chrystusowej nie ograniczały się tylko do życia ziemskiego. Samo zaś Credo było niezwykle przydatne w rozważaniach chrystologicznych, przede wszystkim dzięki artykułom odnoszącym się sensu stricto do osoby Syna.

$* * *$

Hieronim brał aktywny udział w życiu i kwestiach miejscowego Kościoła. Po nim atmosfera kontrowersji doktrynalnych będzie coraz gorętsza, przede wszystkim po soborze w Chalcedonie. Od połowy V do VII wieku dyskusje teologiczne będą dotyczyć problematyki chrystologicznej. W tym okresie Pa-

${ }^{152}$ Myśl tę wyraża starożytna homilia paschalna przypisywana Melitonowi z Sardes.

153 Ambroży mówi o "naturze kompletnego człowieka”, por. De incarnationis Dominicae sacramento VII 76.

154 Tractatus in Ps 15, 9-10, CCL 78, 382-383.

155 Interpretacja Ps 15 nosi wyraźne cechy Dydymiańskie. Egzegeta aleksandryjski twierdzi, że Logos „stał się ciałem obdarzonym duszą” (De Trinitate III 21), a nie „bez duszy”, jak utrzymywali arianie; Dydym Ślepy twierdzi równiez, że dusza Chrystusa charakteryzowała się odruchami ludzkimi, lecz „rozumnymi i współistotnymi dla ludzi” (In Ps 15, 9). Analogie pomiędzy Hieronimem a Dydymem podkreśla A. Gerché (La christologie du „Commentaire sur les Psaumes", s. 193-197).

156 Hieronim wspomina o miejscu, ,gdzie zostalo złożone ciało Pana" i często nazywa je „grotą" (Epistula 108, 9, CSEL 55, 315); por. S. Cola, S. Girolamo. Le lettere, t. 1, Roma 1960, 350-351.

157 Tractatus in Ps 15, 9-10, CCL 78, 381. Epifaniusz z Salaminy snuje podobne rozważania w Adversus haereses III 77, 14. 
lestyna dała bardzo wiele pod względem egzegetycznym, duchowym i politycznym Kościołowi powszechnemu. Trudno jednak było dorównać w tym względzie osiadłemu przy Grocie Narodzenia Strydończykowi.

Hieronimowi przyszło żyć w czasie, gdy ukształtował się już specyficzny język chrystologii i okrzepła doktryna, która doprowadziła do definicji Chalcedonu. W drugiej połowie IV i na początku $\mathrm{V}$ wieku teologowie chrześcijańscy podkreślali, że Słowo - Syn Boży, chociaż nie podlegający ludzkim uczuciom, przyjął jednak odruchy ludzkiej natury, w którą się przyoblekł, żyjąc w sposób tak doskonały, że stanowi niedościgły wzór dla całej ludzkości.

W przypadku refleksji przedstawionej przez Strydończyka należałoby mówić o relacjach, jakie zachodzą pomiędzy kwestiami chrystologicznymi, a jego egzegezą i polemikami. Autor Wulgaty nie tworzy syntezy dotyczącej osoby Zbawcy, lecz uważa prawdę o Nim za nierozłączny element chrześcijańskiego dziedzictwa. Włączanie problematyki chrystologicznej w różnorodne konteksty uwidacznia, że nie uważał on dogmatów za osobną sferę, odłączoną od szeroko pojętej kultury. U Hieronima prawda o Chrystusie znajduje się w dialektycznym napięciu po to, aby mogły być odkrywane jej różnorodne aspekty.

W 1. poł. V wieku Kościół jerozolimski wydawał się być jeszcze daleko od niezdrowych fermentów teologicznych, które rozwinęły się później. Palestyna przyjęła teologię Cyryla i popierała politykę aleksandryjską wobec Nestoriusza oraz całej tradycji antiocheńskiej. Było to przyczyną pojawienia się niechęci i opieszałości w przyjmowaniu dogmatu Chalcedonu. Wybór kierunku prochalcedońskiego nie był więc zrozumiały w całej pełni dla sporej części wiernych w Ziemi Swiętej i wzbudził podejrzenia u mnichów palestyńskich, którzy niejednokrotnie ujawniali swój konserwatyzm w kwestiach doktrynalnych.

\section{THE CHRISTOLOGY OF ST. JEROME IN THE CONTEXT OF PALESTI- NIAN THEOLOGY OF THE IV AND V CENTURY}

\section{(Summary)}

The Palestinian Church gave the remarkable contribution to patristic Christology. Origen and Eusebius gave the response to the developments of theology and dogma. This particular view of Christology was fostered the special conditions of the Holy Land, as one can see at first in the fourth century with Cyril of Jerusalem, then with Jerome in the fifth. The Holy Land was very favourable to a process of synthesis among different theological traditions and Jerome follows faithfully the footsteps of Origen. The testimony of the Latin exegete shows us the principal points of Christological doctrine. It is necessary to consider his biblical and theological reflections in 
the peculiar religious context of Palestine, which preserved the traces of Jesus' life, death and resurrection. Jerome's answer to the Christological questions develops from the point of view of the traditional Christological doctrine, but principally his reflections contribute to a more precise understanding of God's Son humanity. In the manger of Bethlehem the Latin exegete recognise a primary symbol for the essential truth of Christianity: the message of the God who became himself man out of his loving mercy for humankind and chose to be poor. In some points of his exegetical works the Latin doctor insists that Christ possessed a soul capable of suffering from the passions and the desires of the body, though he did not commit sin. Jerome views the Son's relation with the Father and the Holy Spirit as a mystery inexplicable to the human mind and only attainable by faith. 